\title{
FAKTOROK, MAGYARÁZATOK A SIKERES ÉS SIKERTELEN FELSŐOKTATÁSI TANULMÁNYI TELJESÍTMÉNY HÁTTERÉBEN
}

\section{A pszichológiai tényezók szerepe a lemorzsolódásban}

\author{
DR. KŐRÖSSY JUDIT ${ }^{1}$ - JAGODICS BALÁZS ${ }^{1 *}$ - DR. MARTOS TAMÁS ${ }^{2}-$ \\ DR. SZABÓ ÉVA ${ }^{1}$
}

\author{
${ }^{1}$ SZTE-BTK Pszichológiai Intézet, Szociál- és Fejlôdéspszichológiai Tanszék \\ ${ }^{2}$ SZTE-BTK Pszichológiai Intézet, Személyiség-, Klinikai és Egészségpszichológiai Tanszék \\ E-mail: balazs.jagodics@gmail.com
}

Benyújtva: 2020. április 28. - Elfogadva: 2021. március 23.

Célkitűzés: Az utóbbi évtizedek egyik legjelentôsebb felsôoktatási problémája a nagyarányú hallgatói lemorzsolódás vagy a diploma nélküli kilépés. A jelenség megértéséhez többféle elméleti és módszertani megközelítést használtak a kutatók. Tanulmányunk célja, hogy áttekintést nyújtson a lemorzsolódás témában megjelenô cikkek szemléletmódjáról, fókuszpontjáról és néhány eredményéról. A különbözố megközelítésmódok bemutatása segítheti a meglévö ismeretek integrálását, a további kutatások megtervezését és a beavatkozás programjainak kialakítását.

Módszertan: A lemorzsolódást vizsgáló magyar és angol nyelvü tanulmányok kiválasztása online adatbázisokból történt maghatározott kulcsszavak alkalmazásával. A tanulmányokat a kutatási módszerek (változó és személyorientált módszer) és a vizsgálatok fókuszában álló kérdések (lemorzsolódás okai, müködési modellek, változók csoportjainak súlya, hallgatók alkalmazkodási mintázata) alapján soroltuk csoportokba. Eredmények: A témával foglalkozó szakirodalmi anyag áttekintése során négyféle csoport rajzolódott ki. Ezek közül három a változóorientált elemzést alkalmazta, míg a negyedik a személyorientált vizsgálatok csoportját alkotta. A tanulmány részletesen bemutatja e négy témacsoportot: 1. Befolyásoló vagy okozó faktorok csoportositása; 2. A lemorzsolódást magyarázó modellek; 3. Pszichológiai változók és ezek súlyának azonositása; 4. Különbözố változók mintázata alapján kialakított hallgatói csoportok tanulmányi alkalmazkodása.

Következtetések: A megvitatás kiemeli az egyes megközelitésmódok elönyeit és gyenge pontjait a lemorzsolódás jelenségével kapcsolatban. A tanulmány utolsó fejezete azokat az új szempontokat emeli ki, amelyek a további lemorzsolódáskutatásban és az intervenciós programokban is alkalmazhatók.

Kulcsszavak: felsôoktatási tanulmányi sikeresség, lemorzsolódási modellek, változóorientált megközelítés, személyorientált elemzés

" Levelezố szerzô

(C) 2021 A szerzố(k) 


\section{BEVEZETÉS}

A diploma nélküli kilépés a felsôoktatásból, vagyis a lemorzsolódás igen régóta vizsgált terület külföldön és hazánkban is (Pusztai, Fónai és Bocsi, 2019a; Szöllősi, 2019), és ennek során sokféle elméleti és empirikus munka látott napvilágot. A teoretikus írások, valamint a feltáró és elemzô vizsgálatok azt igazolták, hogy a jelenséget befolyásolja a társadalmi-kulturális, oktatáspolitikai, intézményi-szervezeti és családi-egyéni-kortársi tényezốk sokféle mintázatot mutató hatásrendszere. A témakörben megjelent külföldi és hazai tanulmányok nagy része a társadalmi folyamatokba ágyazva vizsgálja a lemorzsolódás okait, szereplőit és a kilépés sokféle, egyént, gazdaságot, felsôoktatási intézményeket és társadalmat is érintô következményeit (Csók és mtsai, 2018; Kerülô, 2018; Pusztai, 2019; Pusztai, Kovács és Hegedûs, 2019b; Pusztai és mtsai, 2019a; továbbá Kovács és mtsai, 2019.). A társadalmi háttér mint magyarázó tényezó mellett a tanulással kapcsolatos kompetenciák, a középiskolai tanulmányok és ennek kapcsán az oktatásügy szerepét is több tanulmány vizsgálja (Molnár és Csapó, 2019; Hódi és Tóth, 2019; Pusztai, 2019). Murtaugh, Burns és Schuster, 1999). Az egyetemi tanulmányok korai befejezésének egyik fôszereplője, formálója és elszenvedôje az egyetemi hallgató, akinek a pszichológiai jellemzôi is hozzájárulnak a sikeres vagy kudarccal teli tanulmányi pályafutás alakulásához. A magyarországi, gazdag ismereteket nyújtó lemorzsolódás-kutatásokban eddig kisebb súllyal jelentek meg azok a cikkek, amelyek a fiatalok pszichológiai attribútumait és ezek szerepét mutatták be a lemorzsolódás folyamatában (például D. Molnár és Gál, 2019; Czakó, Németh és Felvinczi, 2019). Így fontosnak tûnt az általunk tervezett és végzett lemorzsolódás-vizsgálat elôtt, hogy áttekintsük és rendezzük a pszichológia tudományának oldaláról jelentkezô és értelmezhetô faktorokat úgy, hogy közben a jelenség széles körú beágyazottságának ismeretérôl sem mondunk le.

Jelen tanulmány célja, hogy releváns csoportok kijelölésével segítsen áttekinteni a lemorzsolódás témában megjelenô, inkább pszichológiai és érintôlegesen szociológiai orientációjú cikkek szemléletmódját, fókuszpontjait és főbb eredményeit. Tanulmányunk részletesen bemutatja az eddig kialakult megközelítésmódokat, ezek erôsségeit, elônyeit és gyenge pontjait, ami végül is a meglévô ismeretek integrálásában, a további kutatások megtervezésében, és a beavatkozás programjainak kialakításában nyújthat segítséget a szakemberek számára.

\section{Az anyaggyüjtés és feldolgozás módszere}

A tanulmányok összegyújtésekor a Google Scholar és az EBSCOHost, ezen belül az Academic Search Complete, az Academic Search Ultimate és az ERIC adatbázisának angol nyelvú, teljes szöveggel letölthetô cikkeit használtuk. A 2000-2020 idôsávra korlátozva a következố keresôszavak alkalmazásával dolgoztunk: dropout, attrition, higher education, university, latent profile analysis. Külön kerestük a modellekre vonatkozó cikkeket, amelynek során a model szót is alkalmaztuk az elóbbiek mellett, de idôkorlát nélkül. A magyar nyelvú cikkek keresését és szelektálását a könyvtári folyóirat-katalógusba és a Google Scholarba írt lemorzsolódás szó alapján végeztük el. 
A tanulmányokat a feldolgozás során két szempont alapján soroltuk csoportokba. A csoportosítás egyik szempontjaként azt választottuk ki, hogy milyen változókat alkalmaztak a vizsgálatokban, modellekben. Itt a változó- és a személyorientált kategóriákat hoztuk létre. Választásunk azért esett erre a szempontra, mert a cikkek áttekintésekor látható volt, hogy ez alapján a lemorzsolódás és bennmaradás témája új szemléletmóddal gazdagodott. A csoportok kialakításának másik szempontját a vizsgálatok fókuszában álló kérdések és témák határozták meg. Ez alapján négy nagyobb csoportot alakítottunk ki. Az elsố csoportot a lemorzsolódás okait, illetve befolyásoló tényezôit vizsgáló cikkek képezik. Ennek bemutatása során egy olyan kategóriarendszert ismertetünk részletesen, és illusztrálunk néhány kutatási eredménnyel, amelyet Magyarországon kevésbé említettek, ugyanakkor igen széles körét tartalmazza a hatást gyakorló tényezőknek. E csoport kiemelésével a vizsgált jelenség sokszoros meghatározottságára is utalni kívántunk. A második csoportot a lemorzsolódás jelenségének integráló modelljei alkotják. Ide azokat a korábbi, ismert és empirikusan is tesztelt vagy újabb keletû modelleket soroltuk be, amelyek a fontosabbnak és erôsebbnek vélt tényezôk együttesét és ezek dinamikáját, egymásra gyakorolt hatását ragadják meg akár a kilépés, akár a tanulmányok folytatása szempontjából. A kutatások harmadik csoportja nemcsak a tanulmányi átlagot meghatározó tényezôkre helyezi a hangsúlyt, hanem a sokféle - intellektuális, pszichológiai, tanulással kapcsolatos - faktor egymáshoz képest megjelenô súlyának bemutatására is. Erre a kategóriára - csakúgy, mint az elôzô kettőre - a változóorientált vizsgálati módszer alkalmazása jellemzô. Végül a negyedik csoport a személyorientált vizsgálatok körül rajzolódott ki. Az idesorolt vizsgálatok nem a befolyásoló faktorokat vagy ezek rendszerét, hanem az eltérô módon alkalmazkodó hallgatói csoportokat azonosítják és kötik össze a sikeres vagy kudarcos tanulmányi eredménnyel.

\section{A lemorzsolódás}

Általános jelenségnek tekinthetô Magyarországon és világszerte, hogy a felsôoktatási végzettségűek nagyobb arányban találnak elhelyezkedési lehetôséget, és magasabb jövedelemmel rendelkeznek az alacsonyabb iskolai végzettségúekhez képest, nagyobb biztonságban vannak a gazdasági nehézségek esetén, rugalmasabban alkalmazkodnak a munkalehetôségek beszúküléséhez vagy a változó foglalkoztatási környezethez (Quinn, 2013; Varga, 2010), a társadalom iskolázottsági szintje pedig összefügg a gazdaság fejlődésével és versenyképességével (Lukács és Sebő, 2015). Ezek alapján a társadalom és a személyek számára is fontos szempont, hogy egy-egy korosztályból hányan kezdik el és fejezik be sikeresen a felsôoktatási tanulmányaikat. A mai európai felsôoktatási helyzetképre az jellemzô, hogy bár nagy számban lépnek be a fiatalok az egyetem kapuin, átlagosan 30\%-ra tehetô az egyetemet be nem fejezôk, vagyis a lemorzsolódók aránya (Lukács és Sebô, 2015; Varga, 2010), és a magyarországi lemorzsolódási ráta is több éve igen magasnak mondható (Ceglédi, 2019; Pusztai és mtsai, 2019a). Egyéni és gazdasági szempontból is lényeges kérdés tehát, hogy mivel magyarázható a nagymértékú lemorzsolódás, milyen folyamatok húzódnak meg az egyetemrôl való kilépés mögött, milyen pontokon és hogyan lehet segíteni a tanulmányok sikeres elvégzését, 
és milyen szervezeteknek, csoportoknak van lehetôsége, kompetenciája a veszélyeztetett hallgatók támogatására.

A felsôoktatási tanulmányok elvégzésével és a lemorzsolódás arányaival kapcsolatos kutatási eredményekrôl nehéz árnyalt képet kapni, akár még csak az európai országok tekintetében is. Ez részben azzal magyarázható, hogy a tanulmányok végzésének, befejezésének és a lemorzsolódásnak a fogalmait különbözóképpen definiálják az egyes országokban. A másik magyarázatot a mérési sokféleség adja, ami részben a fogalmi heterogenitásból, részben az elérhetô adatok sajátosságaiból származik. Így a lemorzsolódás statisztikai vizsgálata is sokféle módon történik (Szemerszki, 2018; Lukács és Sebő, 2015). Arról sem szabad megfeledkezni ugyanakkor, hogy a különbözô országok felsôoktatási szerkezete, pl. a kurzusok sorrendi kötöttsége, idôtartama, illetve a hallgatói csoportok homogenitása igen eltérô képet mutat, és ez is befolyásolja a lemorzsolódás arányait (Quinn, 2013).

A felsôoktatási tanulmányok befejezését legegyszerúbben azon hallgatók arányával határozhatjuk meg, akik a képzésben, illetve intézményben maradva megszerzik a végzettséget igazoló oklevelet. Igy szinte a lemorzsolódást is meghatározzuk azoknak a fiataloknak az arányával, akik diplomaszerzés nélkül hagyják el az intézményt. De a meghatározás bonyolultabbá válik, ha figyelembe vesszük, hogy több országban a befejezôk közé sorolják azokat is, akik nem az adott egyetem falain belül maradva szereznek felsôfokú végzettséget, hanem más intézménybe vagy képzésbe lépnek át, vagy akár más országban fejezik be a tanulmányaikat (Szemerszki, 2018). A „lemorzsolódás” kifejezés ugyanakkor azt sugallja, hogy a hallgató végleg kimarad a felsôoktatási képzésból, de néhány vizsgálat azt igazolja, hogy ezek a fiatalok sok esetben késóbbre halasztják a tanulmányok befejezését, és évekkel késôbb folytatják a jóval korábban megkezdett tanulmányaikat (Quinn, 2013). A lemorzsolódás definiálásában tehát a képzóhely által megszabott tanulmányi idô is fontos szempont. Varga (2010) például lemorzsolódott hallgatóként azonosítja azokat az egyetemi felvételt nyert fiatalokat, akik a formális tanulmányi idôre nem szereznek diplomát, jóllehet megemlíti, hogy e csoport egy része késôbb vagy más képzôhelyen mégis befejezi a felsôoktatási tanulmányait. További fontos szempont, hogy vajon a diploma nélküli abszolutóriumot megszerzố hallgatókat a lemorzsolódók vagy a képzést befejezók közé soroljuk (Czakó és mtsai, 2019). Az egyén vagy a társadalom oldaláról szemlélve is felvethetô az a kérdés, hogy a diploma nélkül záródó, csak néhány évre korlátozódó felsôoktatási tanulmányokban való részvétel vajon veszteségnek és lemorzsolódásnak könyvelhetô el, vagy a megszerzett tudás és ez elért pszichés fejlôdés jelentôs humán tôkének tekinthetô, amely valamilyen formában megtérülhet (Pusztai és mtsai, 2019b). Az egyetem elhagyása néhány esetben nem a hallgató aktív kilépését jelenti, hanem az intézmény függeszti fel a hallgatói jogviszonyt a túl sok passzív félév, fegyelmi eljárás vagy a sok sikertelen vizsgaalkalom miatt. Több esetben a költségtérítés vállalásának megszüntetése is megjelenik a kilépés okaként (Dinyáné, Pusztai és Szemerszki, 2019). Quinn (2013) összefoglaló tanulmányában felhívja a figyelmet a sokféle szóhasználatra, kifejezésekre, amelyek ugyanakkor arra is utalnak, hogy a lemorzsolódásért, kilépésért, nem teljesítésért, hallgatói mobilitásért alapvetôen az egyént vagy az intézményt terheli-e a felelősség. Összességében tehát azt mondhatjuk, hogy mind a tanulmányok folytatásának, mind a lemorzsolódásnak a meghatározása és mérése nagyon különbözô módon történhet (ld. Pusztai, 2018b; Szemerszki, 2018). 
Nemcsak gazdasági szempontból fontos a tanulmányok sikeres folytatása és befejezése, hanem a felsôoktatási intézményeknek is alapvetô érdeke, hogy nagyszámú hallgatónak nyújtson értékes képzést. Az oktatás vonzó jellegének egyik mutatója éppen az, hogy milyen arányban fejezik be tanulmányaikat a beiratkozott hallgatók. Az intézményi érdek mellett hangsúlyozni kell a hallgatók egyéni, személyes törekvéseit, céljait is, amelyek persze nem mindig jelentenek egyet az elsônek választott szak befejezésével. Sokszor a megfelelố tartalmú és orientációjú szak kiválasztását, megtalálását értjük a sikeres képzés fogalmán, így az új szakra/intézménybe való jelentkezést, sốt a képzés késôbbi folytatását is sikeres befejezésnek tekinthetjük.

\section{A lemorzsolódás arányai az EU-ban és Magyarországon}

A 2007-es adatok szerint az OECD-országokban, illetve az EU19-országokban 29-30\%-os volt a diploma nélkül kilépók száma (Varga, 2010). A 2013-as Quinn-jelentés szerint Dánia (80\%), az Egyesült Királyság (79\%) és Németország $(75 \%)$ hallgatói fejezik be a legnagyobb arányban a megkezdett egyetemi képzést. A legkisebb diplomaszerzési arány pedig Lengyelországban (62\%), Magyarországon (48\%) és Olaszországban (46\%), tapasztalható. A jelentés azt is tartalmazza, hogy leginkább a hátrányos társadalmi-gazdasági környezetból származókat, a férfiakat, a kisebbségi csoportok tagjait és a fogyatékkal élőket érinti a kimaradás veszélye. Sokan azt feltételezték, hogy a felsôoktatás kiszélesítése, tömegessé válása áll a nagyarányú kimaradás mögött, de ezt cáfolják azok az országok, ahol sokféle rétegból érkeznek a hallgatók, mégis magas a sikeres befejezés aránya (pl. Dánia). Az intézmény elhagyásának tényezôi közül leginkább a bizonytalan társadalmi és gazdasági háttér magyarázza a lemorzsolódást.

A magyarországi lemorzsolódás magas aránya tartósan jelen van a felsôoktatásban. Egy 2007-es mérés szerint 45\%-os a diplomát meg nem szerzók aránya (Varga, 2010), a 2009/10-es tanévben pedig az alap- és osztatlan képzésben 36-38\%-os a diploma nélkül kilépôk aránya az SZTE-n (Lukács és Sebô, 2015). A 2015-bôl származó mérés szerint az alapképzést be nem fejezók aránya 36-38\%, a mesterképzést elhagyók viszont csak 14-17\%-át jelentik a beiratkozott hallgatóknak (Derényi, 2015, id. Szemerszki, 2018). A lemorzsolódási arányok változatosságát a különbözô tanévek kiemelése és a mérési módszerek eltérései magyarázzák. Túl a sokféleségen, az adatok arra is rámutatnak, hogy a gazdasági növekedés motorjának tekintett felsôoktatási képzés hatékonysága közel sem optimális, nem biztosítja ugyanis kellô mértékben a társadalmi fejlődéshez szükséges szellemi tôkét.

\section{A LEMORZSOLÓDÁS HÁTTERE, FONTOSABB FAKTORAI}

A megkezdett felsôoktatási képzésbôl való lemorzsolódás egy olyan folyamatként érthetố meg, amelyben sokféle okot, magyarázó tényezôt ismerhetünk fel, és ezek a befolyásoló faktorok egymással összefonódva hatnak a hallgatók tanulmányaira, menni vagy maradni döntésére (Quinn, 2013; Csók és mtsai, 2018; Kerülő, 2018; Miskolczi, Bársony és Király, 2018; Pusztai, 2019). A magyarországi tanulmányokban többféle csoportosítását találjuk meg a lemorzsolódást valószínúsítô tényezóknek. Kerülő (2018) a 
Magyar Rektori Konferencia vizsgálati anyagának elemzéséból készítette a következô hat tényezốcsoportot: intézményi, tantárggyal kapcsolatos, jogszabályi, középiskolai, oktatói és hallgatói tényezôk, amelyek elsôsorban a felsôoktatás keretei között írják le a kilépés vagy maradás meghatározó elemeit. Miskolczi és munkatársai (2018) négy csoportba sorolták a lemorzsolódás fontosabb faktorait: gazdasági, pedagógiai-pszichológiai, társas-kulturális és intézményi, amely tényezôk megjelenítik a lemorzsolódás szélesebb, gazdasági és társadalmi kontextusát is. Olyan faktorokat is említenek külföldi és hazai szerzók, amelyek három csoportot alkotnak a hallgató - intézmény - külsó hatások kapcsolatában (Pusztai, 2019; Doll, Eslami és Walters, 2013). A pull, a kívülrôl húzó faktorok a hallgatók belsô ösztönzôit terelik el a tanulmányok befejezésétôl, ilyenek például az anyagi problémák, a lehetséges munkaalkalmak, családi változások. A push tényezôk közé tartozik az intézmény belsô múködéséból származó nehézségek (intézmény merev szabályozási rendje, a követelmények és értékelés tisztázatlan vagy teljesíthetetlen normái, nagyon magas tandíj), amelynek során a lemorzsolódás valószínúsége növekszik. A fall out, vagyis a kiesést serkentô faktor nem is mindig aktív döntés következtében alakul ki, sokszor inkább olyan melléktermék, amelyet a személyi és oktatási támogatás elégtelensége hoz létre, és aminek következtében kialakul a lemondás, apátia, például a nem megfelelố tanulmányi előrehaladás miatt.

Quinn (2013) a lemorzsolódást elóidézô tényezôket az alább bemutatott hat csoportba gyújtötte össze, amelyek között az oktatáspolitika is helyet kapott. A szerzô ezeket a faktorokat a különbözô Európai Unióba tartozó országok számára is iránymutatónak vélte a lemorzsolódás megítélésében és kezelésében. E faktorok mindegyike vagy a faktorok egy csoportja együtt befolyásolják a tanulmányok végzésének sikertelenségét, jóllehet nem feltétlen ugyanolyan súllyal jelennek meg az egyének, illetve az egyes országok szintjén. A hat faktor elemeinek bemutatását néhány illusztráló vizsgálat is követi.

A szociokulturális tényezók elsôsorban olyan várakozásokat vagy önbeteljesítô jóslatokat tartalmaznak a családok, a helyi közösség vagy az egyetemi oktatók részérôl, amelyek a nem hagyományos (pl. idôs, fogyatékkal élố, elsô generációs vagy etnikai kisebbséghez tartozó) hallgatók tanulmányi sikerére vagy kudarcára vonatkoznak. Ezek az attitûdök hatással vannak a hallgató önmagáról alkotott megítélésére, így könnyebben elfogadhatóvá teszik számára akár a kimaradás lehetôségét is. Ezen túl a helyi munkaerôpiaci lehetôségek is befolyásolják a fiatal döntését azzal kapcsolatban, hogy menynyire érdemes küzdeni a tanulmányok befejezéséért. Ahogy azt a kilépó hallgatókkal készült interjúk igazolták, a nem tradicionális, munkásosztályba tartozó kanadai hallgatók - a középosztálytól eltérô nyelvi készségeik, öltözködésük, kapcsolati hálójuk alapján - úgy érzik, hogy ôk idegenek az egyetem falai között, nem odaillók, nem tudnak kapcsolatot találni a hallgatótársakkal, és megfelelóbb számukra egy gyakorlatiasabb, alkalmazott szintú továbbtanulási lehetôségre való pályamódosítás (Lehmann, 2007). A családi szociokulturális attitûdök szerepét igazolta az idézett kutatásban az a vizsgálati eredmény is, hogy az egyetem elhagyásában a szülôk is támogatták az egyébként jól teljesítô munkásfiatalokat, míg a középosztálybeli, súlyos tanulmányi kudarcot mutató hallgatók esetében a szülő́k csak sokszoros tanulmányi segítségnyújtás után járultak hozzá a gyermekeik kilépéséhez. 
Strukturális tényezóknek tekinthetôk a társadalmi egyenlőtlenséget fenntartó szegénység, a nemi, faji, rétegbeli hátrányos helyzet. E faktorok megnehezítik a tanulmányok folytatását az alacsony jövedelmú, a továbbtanulást kevéssé értékelô rétegekbôl származó fiatalok számára. Ezek a strukturális tényezôk határozzák meg azt is, hogy milyen színvonalú alap- és középfokú képzésben vehetnek részt a gyerekek és serdülók. A szülők alacsony iskolai végzettségének és szocioökonómiai státuszának hatását a lemorzsolódásra olyan tényezók közvetítik, mint a hallgatók tanulás melletti munkavállalása vagy az egyszülôs családok anyagi nehézségei, illetve a szülői nyomásgyakorlás a családi vállalkozás folytatásával kapcsolatban (Araque, Roldán és Salguero, 2009). A magyarországi lemorzsolódás jelenségének hátterében is megtalálható az anyagiak és a munkavállalás szerepe, ami kiegészül a tanulmányi nehézségekkel, az intézményi segítségnyújtás hiányával és a tanulmányokat érintô motivációvesztéssel, illetve kiábrándulással, továbbá az is igazolható, hogy a tanulást folytatók és a lemorzsolódás rizikójával élő hallgatók között az anyagi stabilitás a legjellemzóbb különbség (Pusztai, Kovács és Hegedús, 2019). A társadalmi egyenlootlenség ugyanakkor sajátos felsôoktatási motivációt és attitúdöt alakíthat ki. Egy szintén hazai vizsgálat azt mutatta, hogy az egyetemi tanulmányaikat be nem fejezô, alacsony iskolai végzettségú családi háttérbôl érkezô fiatalokra kevésbé jellemzô, szemben a magasabb iskolai végzettségú családból származókkal, hogy a képzés tartalmával kapcsolatos elvárások kudarcával vagy a jobb boldogulási lehetôséggel magyarázták volna a felsôoktatási intézmény elhagyását (Pusztai és mtsai, 2019a). A továbbtanulás motivációjaként viszont ôk említették leghangsúlyosabban a kitörés, a társadalmi elôrejutás lehetôségét, náluk tehát a felsôoktatási tanulási lehetôség jóval erôsebb motiváció, mint például a szakhoz kapcsolódó érdeklődés. Ugyanakkor egy, a több vizsgálat alapján készült metaanalízis azt jelezte, hogy az egyetemen maradóknál ezek a strukturális tényezók kevéssé hatnak: az ô esetükben ugyanis a demográfiai változók hatásnagysága igen alacsony a tanulmányi sikerességet tekintve, és a szocioökonómiai státusz csak kismértékben korrelál az egyetemi tanulmányi eredménnyel (Richardson, Abraham és Bond, 2012).

Az olyan politikai tényezók, mint a felsôoktatással kapcsolatos stratégiai döntések, szintén képesek negatívan befolyásolni a hallgatók tanulási lehetôségét és a tanulmányok befejezését, egyrészt a hallgatók anyagi támogatásának csökkentésével vagy alacsony szinten tartásával, másrészt az egyetemek anyagi forrásainak szúkítésével. A dániai jelentôs mértékú ösztöndíjemelés azt igazolta, hogy míg korábban az alacsony szocioökonómiai háttérrel rendelkezô hallgatók valóban nagyobb valószínúséggel maradtak ki az egyetemrôl, a bevezetett ösztöndíjreform éppen az ô esetükben, és különösen a természettudományokat tanulók körében komoly mértékben csökkentette a lemorzsolódás arányát a harmadik tanulmányi évben (Arendt, 2013). Az ösztöndíjak szelektív megerôsítô és támogató hatása figyelhetô meg abban a felmérésben is, amely szerint az állami finanszírozású támogatás az egyetemi jelentkezések számát valóban növelte, de a tanulmányok folytatására nem volt hatással, és elsôsorban azokat a hallgatókat bírta maradásra az adott egyetemen az anyagi támogatás, akik a középosztályhoz tartozva nagyobb adósságot is vállalni tudtak (Herzog, 2005). Az oktatáspolitikai döntések közé sorolható az a magyarországi gyakorlat, amely bizonyos szakokon két nyelvvizsga teljesítéséhez köti az egyetemi diploma megszerzését. E kritérium követ- 
keztében itthon elsôsorban az alacsonyabb iskolai végzettségú családok gyermekei azok, akiknek „bennragad” a diplomája, akik tehát a második nyelvvizsga hiánya miatt nem kapják meg a végsố bizonyítványt, és így a lemorzsolódott csoport létszámát növelik (Pusztai és mtsai, 2019a).

Az intézményi faktor olyan intézményi kultúrának és gyakorlatnak tartható, amely nem támogatja a hallgatók sikeres tanulmányi teljesítményét. Ilyen például a nem megfeleló értékelési rendszer vagy a nem támogató oktatói csoport, akik nem veszik figyelembe a hallgatók különbségeit, de idesorolható az a tanterv és pedagógiai módszer is, amely nem ismeri el a sokféle tudásformát. E tényezôkhöz tartozik még az épületek megközelítésének nehézsége és a fogyatékkal élook szükségleteire való érzékenység hiánya is. Egy empirikus tanulmány szerint az oktatói támogatás észlelése valóban kapcsolatban állt a tanulmányok folytatásának szándékával, különösen azoknál a hallgatóknál, akik úgy érezték, hogy van kapcsolatuk a karral, és a kari oktatók számára fontosak a hallgatók, illetve a tanítás színvonala (Bers és Smith, 1991). A Dél-afrikai Köztársaságban mért adatok szerint pedig a közgazdaságtant hallgatók tanulmányi eredményére pozitív hatással volt a tanári kompetencia, a tanítási módszer és a tananyag minôsége is, a matematikai képességnek viszont nem volt jelentôs szerepe (Ganyaupfu, 2013). Az oktatók korrekt magatartásának hiányával, vagyis az oktatókba vetett bizalom hiányával magyarázta a lemorzsolódott magyar hallgatók (605 fơ) harmada a tanulmányok megszakítását, sôt e csoport kétharmada legalább két szereplôvel kapcsolatos bizalomvesztést jelölt meg a tanulmányi kudarc okaként (Pusztai, 2018a).

A felsôoktatásból való kilépést serkentô személyi tényezókhöz sorolhatók a mentális betegségek, a megélt traumatikus események, és a családi, kortársi, kulturális, munkával kapcsolatos vagy a vallási elkötelezettségek. A mentális problémák és a lemorzsolódás kapcsolatának empirikus vizsgálata azonban éppen azt igazolta, hogy olyan mentális betegségek, mint a kezelt depresszió, szorongás, pszichózis és evési zavarok, nem jósolták be a szociális munkás, nôvér- és egészségügyi szakember képzési szakon a lemorzsolódást, sôt az egészségesek jelentôsen nagyobb aránya hagyta el diploma nélkül e képzéseket, mint a mentális betegségekkel küzdôk (Tamin, 2013). Egy másik vizsgálati eredmény a szorongás és depresszió hátterében álló nehéz életesemények negatív hatására mutatott rá (Andrews és Wilding, 2004). Az alapszakos hallgatók körében vizsgált életesemények elemzése azt igazolta, hogy kontrollálva a belépéskor mutatott szorongásos és depresszív tüneteket, az anyagi nehézségek és a személyes fizikai sérülések járultak hozzá a depresszió elôrejelzéséhez, a szorongás bejóslását viszont egyedül a gyakran említett kapcsolati problémák (szeparáció, a kapcsolat másik tagjának súlyos problémája) tették lehetôvé. A tanulmányok közepén mért gyengébb vizsgateljesítmény az anyagi nehézségekkel állt kapcsolatban, és ezt a kapcsolatot a depressziós tünetek közvetítették. A mentális problémákon túl a családtaggal kapcsolatos gondoskodás felelôssége is negatív hatással lehet a tanulmányok folytatására éppen úgy, mint a választott intézmény térbeli távolsága, idōt igénylô megközelítése. Egy öt évet átfogó adatsort elemzô tanulmány azt igazolta, hogy a más államban lakó egyetemi hallgatók nagyobb valószínúséggel hagyják el az intézményt, mint az adott államban élook, és ennek gyakran a nem megfeleló ösztöndíjrendszer az oka, amely nehezíti a költségesebb megélhetési lehetôségeket (Murtaugh, és mtsai, 1999). 
A tanulási tényezôk a tanulás problémáit és a felsôoktatási képzés gyengeségeit foglalják magukban. Részletesebben kifejtve olyan faktorok tartoznak ide, mint a nem megfelelố belépési kvalitások, problémák az íráskészségben, problémák a saját tudásra való rálátásban és a célok kitúzésében, a nem megfeleloo tanulmányok választása, az órák látogatásának gyakori mellốzése, téves észlelése a tanulmányok és a késôbbi pálya kapcsolatának. A tanulási jellemzôk mellett a kevéssé ösztönzó és a rosszul szervezett oktatás is idetartozik, például az elsô félévben felvehetô alapozó vagy bevezetô kurzusok túl magas színvonala, érthetetlensége, aminek hátterében sokszor a hiányos középiskolai tudás áll (Lendvai, Panyor és Hampel, 2019). Nemcsak az egyes tényezôk befolyásolják a tanulmányi eredményeket, illetve a lemorzsolódást, hanem a több faktor együttesébôl származó latens profilok is jól magyarázzák a felsôoktatási sikereket és kudarcokat. A pályával kapcsolatos elkötelezettség eltéró profiljai, amelyek pl. az önszabályozott tanulás, a tanulással kapcsolatos elkötelezettség, a pályaválasztás bizonyossága és a kimerültség együtt járásából rajzolódtak ki, különbözô tanulmányi teljesítménnyel korreláltak (Ketonen és mtsai, 2016). Tanulmányi eredmény és kreditérték szempontjából az elkötelezett hallgatók teljesítettek a legjobban, akikre jellemzó volt a tanulással kapcsolatos elkötelezettség és a biztos pályaválasztás. A legalacsonyabb tanulmányi teljesítményt az elkötelezettség nélküli csoport (elkötelezettség hiánya, bizonytalanság a pályaválasztásban, kimerültség) érte el, valamint a döntés nélküli profilú csoport (bizonytalan pályaválasztás és kevésbé erôs elkötelezettséghiány) mutatott. Az egyes konkrét motívumok szerepét igazolta az a vizsgálat, amely szerint a magyar, román, szerb és ukrán egyetemi hallgatók elkötelezett tanulmányi munkájára elsôsorban a „tudás gyarapításának” belsố és a „még ne kelljen dolgozni” külsố ösztönzője gyakorolt pozitív hatást, ugyanakkor ezek az öndeterminációs modell alapján meghatározott külsô (ellenôrzött szabályozásként ható, kívülrôl érkezô jutalmazás és büntetés) és belsô (pszichológiai szükségleteket teljesítô) motivációs faktorok csoportja nem befolyásolta a perzisztenciát (Kovács, 2018). A különbözô tanulási motívumok nemcsak a tanulmányi teljesítményt és a tanulmányok folytatását befolyásolják, hanem a lemorzsolódás veszélyének észlelését is. Az olyan vélekedések és motiváló nézetek mintázata, mint a diploma értékességébe vetett hit, a tanulás befejezésével kapcsolatos elkötelezettség és a bennmaradást segítô erôfeszítés, négy különbözô hallgatói csoportot hozott létre, akik másféle társadalmi háttérbôl érkeztek, és eltérôen ítélték meg a tanulmányaik folytatását vagy megváltoztatását, így a lemorzsolódás lehetôségét is (Ceglédi, 2019). Az anómiások kevés erôfeszítést tesznek, nem hisznek a diploma hasznosságában, és ôk azok, akik nagyobb mértékben gondolják, hogy diploma nélkül hagyják el a képzést. A potyázók csoportja nem tesz erófeszítést, de hisz a diploma értékességében, és kevésbé bízik abban, hogy befejezi a tanulmányait. A célorientált perzisztens csoportba tartozók nagy erôfeszítést tesznek, hisznek a diploma értékes voltában, és kevésbé valószínú számukra a tanulmányok diploma nélküli befejezése. A rituális perzisztensek elszántak a tanulmányok befejezésében, nagy erófeszítést tesznek ezért, de nem hisznek a diploma értékében, illetve fontosságában, tehát ók azok, akik rituálisan teljesítik a követelményeket, és a háttérben alacsony önértékelés is elôfordulhat. Egy másik magyarországi vizsgálat azt igazolta, hogy a motiváció hiánya, a tanulmányokkal kapcsolatos kiábrándulás jelzi előre a lemorzsolódással kapcsolatos intenciókat, vagyis a megkezdett félév megszakításának gondolatát (Czakó és mtsai, 
2019). Az amotivációt több pszichés tényezô is bejósolta: pozitívan a depresszív tünetek mennyisége, negatívan a tanulmányi elkötelezettség és az extrinzik identifikációs motiváció. A tanulmányi bevonódást, elkötelezettséget pedig a képzésre vonatkozó elégedettség, a tanulási intrinzik motiváció, a saját teljesítményi elvárások és az észlelt tanulási kompetenciák jelezték elôre. A tanulási tényezôkhöz sorolhatók a tanulmányok folytatásának olyan adatai, mint a kreditszám és a félévi beiratkozás. Ez alapján a magyar orvostanhallgatók esetében (Dinyáné és mtsai, 2019) és az ELTE hallgatóinak vizsgálatában (Czakó és mtsai, 2019) kimutatható volt, hogy a lemorzsolódás esélyét növelte a kreditszám-emelkedés lassulása, a passzív félévek számának növekedése, és a költségtérítéses képzésben való részvétel, vagy az ebbe való átkerülés, miközben a kollégiumi elhelyezés egyfajta védelmet jelentett a kimaradással szemben (Dinyáné és mtsai, 2019).

A hat faktorhoz tartozó tényezốk nemcsak külön-külön hatnak a lemorzsolódásra, hanem egymással is összefüggésben állnak, hiszen például a tanulással kapcsolatos negatív hozzáállás származhat a kevésbé színvonalas oktatásból, de a családi kulturális tốke hiányából is (Quinn, 2013). Emellett Quinn (2013) azt is megemlíti, hogy hasonlóan nehéz körülmények esetén a hallgatók egy része mégis befejezi az egyetemet. A nehézségek ellenére is sikeres hallgatói pályafutás fontos háttértényezőjét láthatjuk például a reményérzésben. A remény két összetevơje, a személyes hatóerő és a megoldási lehetôségek, olyan dinamikus kognitív motivációt jelentenek, amely lehetôvé teszi a hallgatók számára, hogy a problémákat a siker lencséjén keresztül szemléljék. Így azok a hallgatók, akik magas pontszámot értek el a remény skálán, jobb tanulmányi eredményt mutattak fel, és közülük kevesebben hagyták ott a felsôoktatást, mint az alacsony pontszámmal jellemezhetố hallgatók (Snyder és mtsai, 2002).

Szöllôsi Gábor tanulmánya (2019) kitér azokra a további tényezốkre, amelyek, túl az elôbb említetteken, befolyásoló és magyarázó faktoroknak tekinthetôk. A társadalmi változások feltárása, a hallgatói megfontolások döntéselméleti felfogása, valamint a hallgatói élettörténetek, életutak tapasztalatainak figyelembevétele tekinthetôk olyan további szempontoknak, amelyek közelebb vihetik a kutatókat, oktatókat és az egyetem vezetôit a lemorzsolódás megértéséhez és kezeléséhez. A tanulmányok korai feladását új szemlélet mentén magyarázza a szociális konstrukcionista felfogás (Szöllôsi, 2019). E személetmód szerint a lemorzsolódás jelenségének vagy annak egy-egy jellemzôjének az értelmezése, felfogása, magyarázata akár az intézményi részvevók, akár a hallgatók közössége oldaláról fontos befolyásoló, sốt döntố tényezô lehet a tanulmányok folytatásával vagy megszakításával kapcsolatban. Nemcsak a tanulmányokkal, társas érintkezéssel kapcsolatos események, történések hatnak a hallgatói akadémiai viselkedésre, hanem ezeknek a magyarázata is, amelyet a különbözô csoportok az interakciók során alkotnak meg. Az értelmezések tartalmát négy tényezô mentén érdemes vizsgálni a szerzó szerint: 1 . az egyetemi tanulmányok szerepe, értéke; 2 . az egyetem és a hallgató illeszkedésének lehetôsége és normája; 3. a tanulás, tudás, teljesítmény felfogása; 4. az egyetem közösségeihez való tartozás jelentése alapján (Szöllôsi, 2019).

Az említett változók jól leírják a lemorzsolódásra ható tényezôket, de a háttérben olyan társadalmi, gazdasági, demográfiai jellemzók is megtalálhatók a 20-21. század fordulóján, amelyek sajátos keretét adják a hallgató-intézmény megfelelésnek. Somlai azt emeli ki, hogy a posztindusztriális társadalmakban az iskolában töltött idô meg- 
hosszabbodik, a felnôtté válás kitolódik, a posztadoleszcens fiatalok, illetve nemzedékek pályaválasztási döntései többször is módosulhatnak a nem sztenderd életútmintázatok kialakítása során (Somlai, 2011). E társadalmi és gazdasági változás talaján még inkább megérthetố a hallgatók egyetemi évek alatt mutatott pályamódosítása, amely sokszor lemorzsolódásként jelenik meg a statisztikákban.

\section{MODELLEK A HALLGATÓK FELSŐOKTATÁSI PÁLYAFUTÁSÁRÓL}

A lemorzsolódás vagy a tanulmányok folytatásával kapcsolatos tényezók ismerete nem ad választ arra, hogy milyen módon kapcsolódnak össze a legmeghatározóbbnak tekintett változók, és milyen dinamikája, egymásra hatása van a kiemelt tényezók rendszerének. Többféle modell létezik a felsôoktatási kilépés vagy folytatás értelmezésére, amelyek különbözô változók egymásra hatásaként magyarázzák a hallgatók viselkedését. A modellek mindegyike törekszik arra, hogy széles környezeti kontextusba helyezze a hallgatói teljesítmény alakulását, a maradni-menni döntést, az intézménnyel kapcsolatos elkötelezettséget. Az elsố három modellt több vizsgálat is alkalmazta, illetve igazolta, és e modellek szerzôi reflektáltak is egymás munkáira. A negyedikként bemutatott lemorzsolódási útvonal sajátossága az, hogy olyan rövid periódust vizsgál és értelmez (az elsố két szemesztert), amely lemorzsolódás szempontjából a legkritikusabb idôszaknak tekinthetô.

\section{Tinto lemorzsolódásmodellje}

Az egyik legismertebb a Tinto-féle modell, a Lemorzsolódás Longitudinális Modellje (Longitudinal Model of Dropout, Tinto, 1975). A szerzô a lemorzsolódást és a bennmaradást is folyamatként írta le, ahol a képzóhely tanulmányi és társas szerkezetének és a fiatalnak az interakciója hat az egyetemi pályafutásra azáltal, ahogy a céllal és intézménnyel kapcsolatos elkötelezettség formálódik. Belépéskor a családi háttér, egyéni jellemzôk és tapasztalatok (korábbi oktatás) láthatók az egyén oldaláról, amelyek közvetlen és közvetett módon is befolyásolják a teljesítményét, ill. a kezdeti cél-és intézményi elkötelezettséget. Ezek a jellemzók és elkötelezettségek lépnek interakcióba az intézmény strukturális és normatív jellemzôivel, és ez vezet az intézmény társas és tanulmányi rendszerébe történô integrációhoz. Tinto szerint minél nagyobb ez az integráció, annál erôsebb az elkötelezettség a speciális intézménnyel és a befejezés céljával kapcsolatban. Az egyetemi tanulmányok folytatását vagy a kilépést a hallgató befejezéssel kapcsolatos és az intézménnyel kapcsolatos elkötelezettségének a kölcsönhatása fogja megadni (Tinto, 1975; Terenzini és Pascarella, 1980). A hallgatók az egyetemi tanulmányokkal kapcsolatban ár-elôny értékelést végeznek, és akkor lépnek ki, ha úgy észlelik, hogy másféle aktivitásba való befektetés nagyobb előnnyel jár a költséghez képest. Ez a költség-haszon értékelés végül is a befejezéssel és az intézménnyel kapcsolatos elkötelezettségben tükrözódik. Az elemzés, illetve a helyzet észlelése függ az egyéni jellemzóktôl és az intézménytôl is, illetve a kettô interakciójától. 


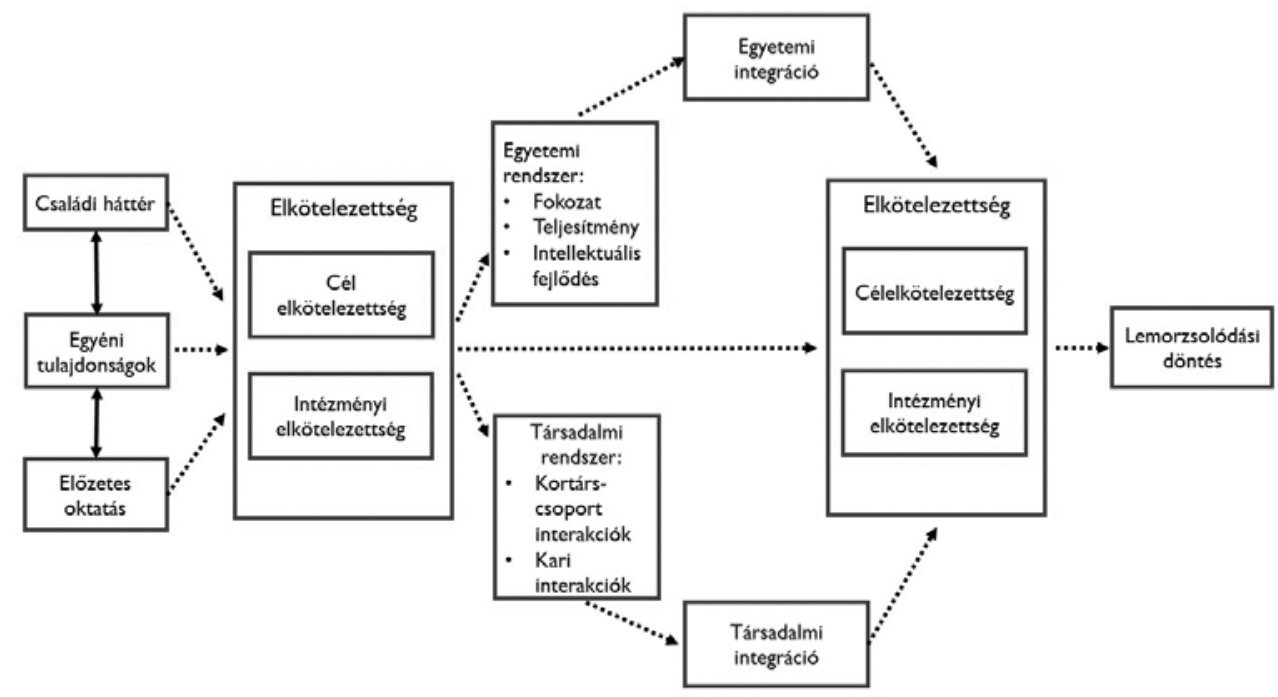

1. ábra. Tinto-féle Lemorzsolódás Longitudinális Modellje (Tinto, 1975, 95)

A modell három szakaszát írta le a hallgató-intézmény interakciónak (1. ábra), így az idôbeli folyamat is fontos szerepet kapott a lemorzsolódás magyarázatában (Tinto, 1987, 1993, id. Elkins, Braxton és James, 2000). A három szakasz a szeparáció, átmenet, inkorporáció elnevezést kapta. Az egyetemi belépéskor kezdődó (és 1., 2. félévben jellemzô) szeparáció a korábbi közösségrôl (család, barátok, középiskola, lakóhely) való leválást jelenti, ami bizonyos mértékig a korábbi közösség normáinak elutasítását is jelenti. Erre a folyamatra hatnak a hallgató jellemzói és korai elkötelezettsége (intézménnyel, szakkal), valamint a szülők, barátok támogatása, ami egyet jelent részükrôl az egyetemi értékek elfogadásával. A sikeres szeparáció szakasz után az átmeneti és az inkorporáció szakasz az, amely végsô soron befolyásolja a maradás vagy kilépés eldöntését.

Az egyik Tinto modelljét alkalmazó tanulmányban három különbözó vizsgálati csoportban is az igazolódott, hogy az intézményi jellemzók, valamint az egyéni jellemzóknek és a tanulmányi és társas integráció komponensének az interakciója jelentôsen hozzájárult a hallgatói kilépéshez (Terenzini és Pascarella, 1980). Ugyanakkor a vizsgálatok eredményei arra is felhívták a figyelmet, hogy a kilépés és a tanulmányok folytatásának eldöntése igen komplex és dinamikus folyamat, amelynek csak néhány elemét sikerült azonosítani.

A szeparáció fázisát és annak meghatározó tényezőit kívánta ellenôrizni Elkins, Braxton és James (2000) vizsgálata, amelyben 411 elsó évfolyamos hallgató vett részt. Az útelemzés azt mutatta, hogy a családi, baráti és kortársi támasznak van a legerôsebb hatása a menni/maradni döntésre: akik támogatást észlelnek, azok nagyobb valószínúséggel folytatják a megkezdett tanulmányokat. Az értékek és attitûdök elutasítását is igazolta az elemzés: azok a hallgatók, akik úgy észlelték, hogy el kell utasítaniuk a korábbi értékeiket, nagyobb valószínúséggel iratkoztak be a második szemeszterre. A szerzôk szerint ezek az eredmények igazolják a szeparáció szakaszának létezését, illetve az ebben a szakaszban ható támasznak és értékelutasításnak a „maradni” döntésre kifejtett hatását. 
Az oktatókkal, és még inkább a szülookkel fenntartott (ún. intergenerációs) kapcsolat megtartó hatását igazolta az a magyar vizsgálat, amelyben kelet-magyarországi, ukrán, szlovák, román és szerb területen múködô magyar nyelvú felsôoktatási intézmények hallgatóinak perzisztenciája, felsôoktatási képzésben maradása állt a Tinto-modellt alkalmazó kutatás fókuszában (Pusztai, 2018b). A képzés folytatása jellemzôbb volt a nôi hallgatókra, mint a férfiakra, a szülook iskolai végzettsége ugyanakkor nem befolyásolta a maradás szándékát, a jobb anyagi körülmény viszont éppen ellene hatott. Az elemzés fontos eredménye volt, hogy az intézményi önkéntes hallgatói csoportokban (kortársi, intragenerációs kapcsolatokban) való részvétel inkább csökkentette a maradás szándékát. Az oktatókkal és jelentôsebb mértékben a szülookkel való szoros kapcsolat perzisztenciát magyarázó hatását a szerzók azzal magyarázták, hogy a felsôoktatási intézmények múködését inkább a formalitás és a személytelenség jellemzi, ahol stabil közösségi támogatás csak kevéssé valósul meg, így a szülookkel és az oktatást-kutatást fontosnak tartó oktatókkal való kapcsolat hat legerôsebben a tanulás folytatásának szándékára.

Ugyanakkor azt is érdemes megemlíteni, hogy nem minden vizsgálatnak sikerült igazolni az intézmény erôs hatását. Richardson és munkatársai (2012) a társas integráció mérésére alkalmazott tényezôknél (tanulmányi, társas, intézményi elkötelezettség, céllal kapcsolatos elkötelezettség, társas támasz) csak nagyon kicsi korrelációt talált a tanulmányi eredménnyel. Szerintük ez a gyenge kapcsolat nem igazolja Tinto modelljét.

\section{Bean Hallgatói Kilépés Modellje}

Bean a lemorzsolódás meghatározóin túl oksági összefüggéseket kívánt felvázolni a modelljében (Model of Student Attrition, Bean, 1981a, 1981b). A modell az egyén és a kiválasztott intézmény interakciójára, illetve az egyén-szerep illeszkedésre helyezi a hangsúlyt (2. ábra).

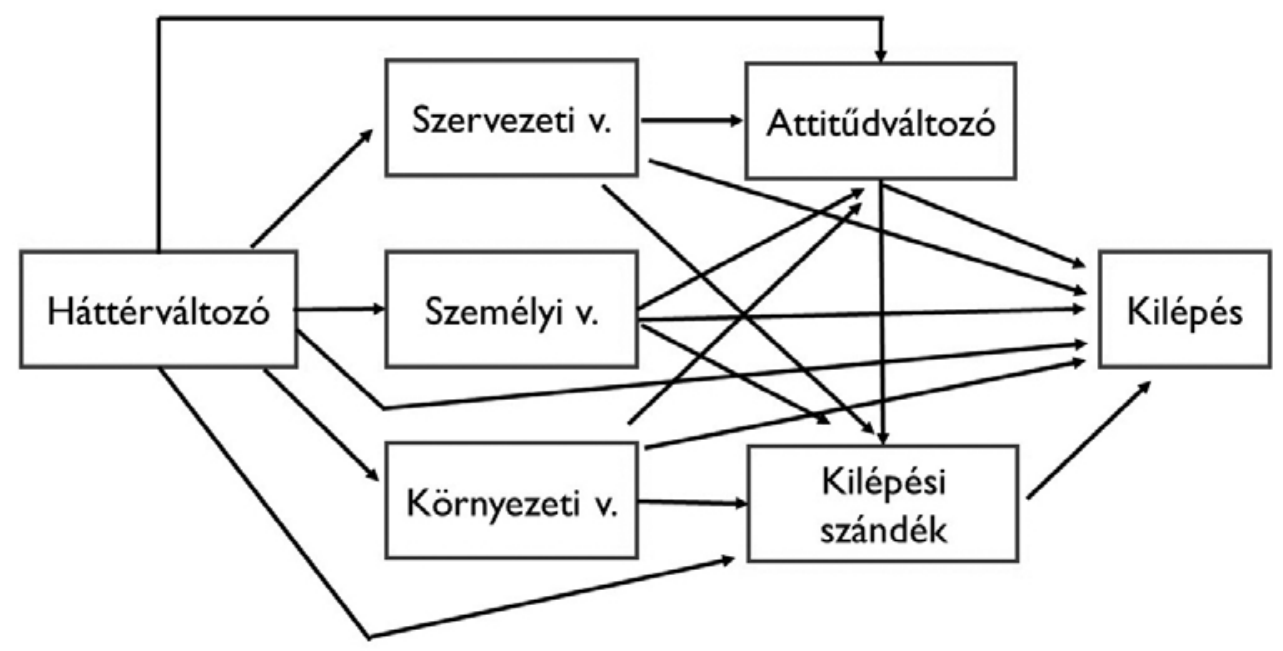

2. ábra. A lemorzsolódással kapcsolatos változók kauzális sorrendje (Bean, 1981a, 39) 
Bean egyik tanulmányában (Bean, 1981b) leírja a modell elemeit, majd egy másik cikkben (Bean, 1981a) a modell operacionalizált változóit és a vizsgálat eredményeit. A háttérváltozók az érettségi elôtti objektív információkat, illetve akár az attitúdöket is magukban foglalják, amelyek a következó módon jelentek meg a lemorzsolódásvizsgálatban: az apa és anya iskolai végzettsége, a középiskolai tanulmányi eredmény, a szülốváros és a középiskolai város nagysága, illetve a szülôváros távolsága. A háttérváltozó hatással van három nagy változóra: a szervezeti, személyi és környezeti változókra. A szervezeti változók, amelyek a hallgató megfigyelésével szerezhetôk meg, olyan tényezókre vonatkoznak, mint az egyetemi szintek, illetve évfolyamok, informális kapcsolat a karral, centralizáltság, tagság a kampusz szervezetében, egyetemi tanulmányi program versenyszerú jellege, órákról való hiányzás, kurzusok elérhetôsége. A személyi változók köre három elemet foglal magába: a céllal való elkötelezettséget (mennyire fontos az alapfokozat befejezése), a szak és foglalkozás választására vonatkozó bizonyosságot és az önbizalmat, magabiztosságot (confidence). A környezeti változók pedig olyan tényezóket jelentenek, amelyekre sem az intézmény, sem annak tagjai nincsenek hatással, de amelyek fontosak a menni vagy maradni döntésben. Ezt a következô elemek mérésével operacionalizálta a szerzô: átlépési lehetôség egy másik intézménybe, házasságkötés valószínúsége, tanulás financiális könnyúsége, az intézmény családi elfogadása. Az attitûdváltozó, amelyet befolyásol az elôbbi négy változócsoport, az egyén és intézmény interakciójának pszichológiai következményét jelenti, ez tehát egyfajta értékelése az egyén tapasztalatainak. Ezen belül négy tényezôt vizsgált a szerzô: húség, vagyis a diplomaszerzés fontossága az adott egyetemrôl, a választás biztossága (mennyire biztos az intézmény választásában), elégedettség a hallgatói léttel, és végül a gyakorlati értékek észlelése (ami a képzés hasznosságát jelenti a munkavállalás szempontjából). A modell értelmében az itt bemutatott öt változó következményeként jöhet létre a kilépési szándék, amely végül a tényleges kilépést okozhatja. Bean (1981a, 1981b) a kilépési szándékot Ajzen és Fishbein (1973) munkájára alapozva emelte ki, akik szerint a szándékot az attitûdök, normák és az elôzô viselkedés határozza meg, a szándék pedig meghatározza a hozzá kapcsolódó viselkedést. Eszerint tehát a kilépési szándék gyakorolja a legnagyobb hatást a kilépési döntésre, illetve a tényleges kilépésre.

Bean néhány fontos különbséget lát Tinto modellje és a sajátja között (Bean, 1981a). Hangsúlyozza, hogy Tintónál hiányoznak a szervezeti és a személyi változók mint külön kategóriák, illetve a Tinto-féle modellben csak a céllal való elkötelezettség szerepel hangsúlyosan a személyi változók közül. A környezeti változók is csak a beani modellben kaptak helyet, továbbá az attitúdökbôl csak az elégedettséget említi Tinto. A kilépési szándék mint a kilépés közvetlen meghatározója is csak Bean modelljében szerepel, hiszen Tinto kilépési döntésrôl és nem attitûdrôl beszél, ami akár a tanulmányok folytatását is jelentheti.

A közel kétezer elsô évfolyamos hallgató vizsgálata során kapott eredmények alapvetốen igazolták a modell szerkezetét és a változók közötti kapcsolatokat (Bean, 1981a). A nemi különbségek mellett a magabiztosság jelent meg mint csoportalkotó tényezó, így nagy és kevés önbizalommal rendelkezô férfi és nôi csoportokkal végezte a szerzó a regresszióelemzést, illetve az útanalízist. Mind a négy hallgatói csoportban a kilépési szándék volt a legerôsebb elôrejelzôje a kilépésnek, és a lemorzsolódás varianciájának 43-52\%-át tudta magyarázni a változók némileg különbözó konstellációja. Bean 
(1981b) szerint a modell erejét igazolja az, hogy a lemorzsolódás varianciájának átlagosan 50\%-át volt képes magyarázni a változók e sajátos rendszere. A szerzô szerint a sikeres modellalkotás egyrészt az attitúdváltozók és a kilépési szándék beemelésével magyarázható, másrészt a változók operacionalizálásával. A vizsgálat empirikusan is igazolta, hogy a lemorzsolódás legerôsebb elôrejelzôje a kilépési szándék, és ez elsôsorban abból a szempontból fontos eredmény, hogy már a tényleges kilépés előtt mérhetố a hallgatóknál ez az elképzelés, és így az intézmény tanácsadással vagy egyéb segítô, támogató eljárással be tud avatkozni a folyamatba (Bean, 1981a).

\section{Cabrera, Nora és Castaneda: a Hallgató Kilépés Integrált Modellje}

Tinto Lemorzsolódás Longitudinális Modelljét és Bean Hallgatói Kilépés Modelljét ötvözte Cabrera, Nora és Castaneda (1993) tanulmánya azon az alapon, hogy ezek számos ponton hasonlóságot mutatnak, például a sokféle befolyásoló tényezó interakciója, a hallgatók elôzetes jellemzői, az egyén és az intézmény összeillése.

A két modellt egy hipotetikus modellben integrálták a szerzók (Integrated Model of Student Retention), és 466 elsô évfolyamos hallgató adatain tesztelték egy longitudinális vizsgálatban. Az összevont modell valóban jobban magyarázta a tanulmányok folytatását (3. ábra), mint a korábbiak. A környezeti változókról (bátorítás a családtól, barátoktól, pénzügyi támogatással kapcsolatos attitúd) pedig az derült ki, hogy - eltérôen Tinto elképzelésétôl - nemcsak az elkötelezettségre gyakoroltak hatást, hanem az elkötelezettséget befolyásoló tanulmányi tapasztalatokra (tanulmányi teljesítménynyel és tantervvel való elégedettség, az elképzelt szint teljesítése) és a hallgatók társas integrációjára is (közeli kapcsolatok és barátság kialakítására).

A modell a tanulmányok folytatását (perzisztencia) és ennek szándékát kívánja magyarázni. A vizsgálati eredmények szerint a perzisztenciára a legnagyobb hatást a

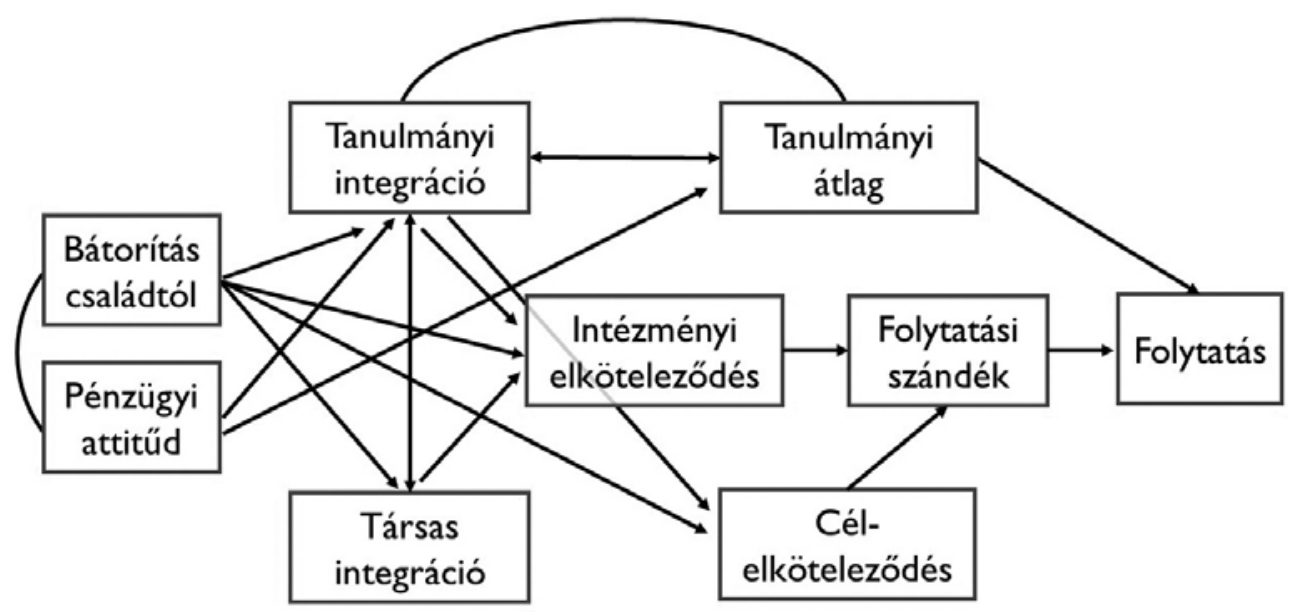

3. ábra. A tanulmányok folytatásának strukturális modellje a szignifikáns kapcsolatok jelzéseivel (Cabrera és mtsai, 1993, 134) 
folytatási szándék gyakorolta, majd csökkenô sorrendben a tanulmányi eredmény, intézményi elkötelezettség, bátorítás (családtól, barátoktól), céllal való elkötelezettség, tanulmányi integráció, financiális attitûdök és a társas integráció. A maradási szándékot pedig legerôsebben az intézményi elkötelezettség magyarázta, majd csökkenô sorrendben a bátorítás, céllal való elkötelezettség, tanulmányi integráció, társas integráció, pénzügyi attitûd.

\section{Bennett modellje a menni-maradni döntésról}

Bennett (2003, id. Lukács és Sebô, 2015) modellje sok szempontból hasonlít az elôzô három modellhez, elsôsorban ami a hallgatóval kapcsolatos változókat illeti, de - eltérốen az előzôktôl - igen rövid idôtartamú, az elsô két félévet átfogó vizsgálat eredményeibôl rajzolódott ki. Az útvonalmodell szerint a tanulmányokkal kapcsolatos elkötelezettség az egyik kulcstényezó, amelyre hat a személyes befektetés mértéke, a megelégedettég (a tanítással és az egyetem szolgáltatásaival) és a motiváció. A motivációt befolyásolja a stresszen keresztül a tanulmányi teljesítmény és a szak megtartó ereje. A tanulmányi teljesítményre viszont hatnak a tanulási szokások és a képességek. A tanulmányi teljesítmény ugyanakkor kapcsolatban áll az önbecsüléssel (mennyire bízik a képességeiben). A maradni/kilépni döntést a tanulmányi teljesítmény és az elkötelezettség befolyásolja, de hat rá a személyes problémák és anyagi nehézségek változója is. Miskolczi és munkatársai (2018) azt emelik ki a bennetti modell és eredmények bemutatásakor, hogy az alacsony jövedelmú és etnikai kisebbségbool érkezó majdnem 400 fônyi fiatalt érintô vizsgálat szerint a kilépés eldöntésére legnagyobb mértékben az anyagi nehézségek hatottak. Az anyagi problémák hatását módosította

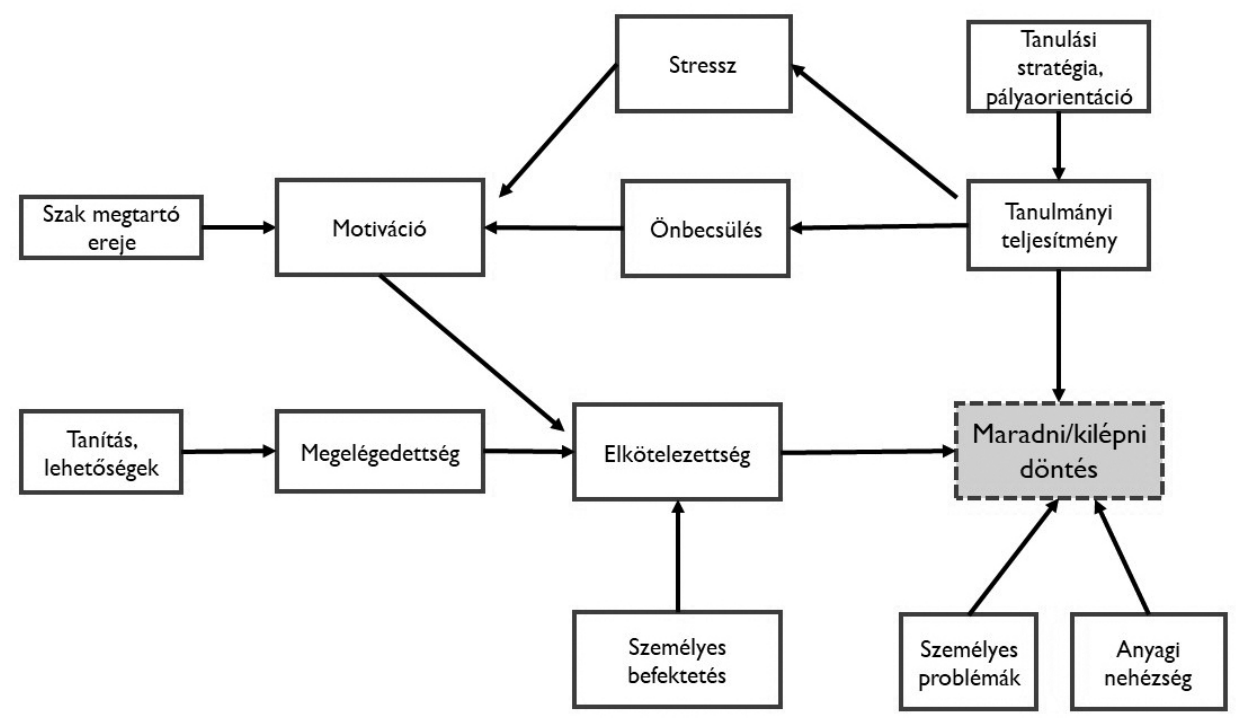

4. ábra. Bennett modellje a maradni vagy kilépni döntésről (Lukács és Sebô, 2015, 84 alapján) 
az elkötelezettség, tanulmányi teljesítmény és az önbecsülés, vagyis azok a hallgatók hagyják el a képzést pénzügyi nehézségek esetén, akik nem tanulnak jól, nem kitartók és elkötelezettek, vagy kevésbé értékelték magukat pozitívan. A kilépést valószínúsítették még váratlan problémák és a tanulmányi teljesítmény is. A jobb jövedelmú és tandíjat fizetô hallgatók jobb tanulmányi eredményt értek el, és motiváltabbak voltak, így az anyagi biztonság pozitív hatása igazolható jelenség volt.

\section{A SIKERES FELSŐOKTATÁSI TANULMÁNYOK PSZICHOLÓGIAI HÁTTERE, FELTÉTELEI, AZ EGYES TÉNYEZÖK SÚLYA}

Sokféle különbözó pszichológiai konstruktum hat az egyetemi tanulmányok sikeres vagy kudarcos teljesítésére, és ezzel kapcsolatban több kérdés is felmerül. Lényeges szempont az, hogy mennyire van szoros kapcsolatban az egyetemi tanulmányi teljesítmény a korábbi tanulmányi eredménnyel, a kognitív képességekkel és a sokféle, nem kognitív konstruktummal, illetve milyen mértékben tudják ezek a tényezók magyarázni a tanulmányi elômenetelt. Az is fontos szempont, hogy mik azok a tényezók, amelyek a legszorosabb kapcsolatban állnak a jó tanulmányi eredménnyel. Ezek a kérdések foglalkoztatták Richardsont és munkatársait (2012), amikor a 13 év során megjelenô több mint 7000 tanulmány metaelemzését végezték el azzal a céllal, hogy feltárják, mely változók mutatják a legszorosabb együtt járást az egyetemi tanulmányi átlaggal. Az alapszakos hallgatók körére szúkített vizsgálatokból független változóként 3 demográfiai tényezôt (nem, életkor, szocioökonómiai státusz), 5 kognitív faktort (két képességvizsgáló teszt eredményét, két középiskolai teljesítményt mérô pontszámot, intelligencia-pontszámot), és 42 nem intellektuális konstruktumot emeltek ki. A nem intellektuális tényezôk öt csoportját határozták meg: 1. személyiségvonások, 2. motivációs tényezók, 3. önszabályozott tanulási stratégia, 4. tanuláshoz való hozzáállás, 5. pszichoszociális tényezók. A végül 400 cikkre szúkített tanulmánygyújtemény feldolgozott korrelációs eredményei szerint az egyetemi tanulmányi eredménnyel kismértékben pozitívan korrelált az általános intelligencia, és közepesen erôsen a középiskolai eredmények és a képességtesztek. Gyenge korrelációt mutatott a szocioökonómiai státusz, a nem és az életkor (jobb osztályzatot értek el a nôi, idôsebb és magasabb rétegbe tartozó hallgatók). A nem intellektuális tényezók esetén csak három személyiségtényezô mutatott gyenge korrelációt, ezek a halogatás (negatív korreláció), a lelkiismeretesség és a megismerési szükséglet (mindkettô pozitív korreláció). A motivációs tényezôk közül közepesen erôsen pozitívan korrelált a tanulási énhatékonyság és az osztályzatra vonatkozó cél, és ugyancsak pozitív módon, de erôsen a teljesítmény-énhatékonyság. Az önszabályozott tanulási stratégiák közül az erőfeszítés szabályozása közepesen erôsen pozitívan, a tesztszorongás gyengébben és negatívan járt együtt az egyetemi tanulmányi eredménnyel. Emellett még gyenge negatív együtt járást mutatott az általános és tanulmányi stressz, és gyenge pozitívat a stratégiai tanulási hozzáállás. A szerzốk külön kiemelték, hogy a nem kognitív tényezôk közül a legerôsebb kapcsolatot a teljesítmény és az akadémiai/tanulási énhatékonyság, az osztályzatra vonatkozó cél, valamint az erôfeszítés szabályozása mutat az egyetemi átlaggal. Éppen ezek azok, amelyek potenciálisan módosítható kognitív és önszabályozási tényezôk az 
egyetemi pályafutás során. A stabilabbnak tekinthetô személyiségjellemzôk, a tanuláshoz való hozzáállás és a pszichoszociális kontextuális tényezôk viszont nem kapcsolódtak szorosan, még csak közepes mértékben sem az egyetemi tanulmányi sikerességhez. A szerzôk szerint ugyanakkor a gyenge korrelációt sem szabad figyelmen kívül hagyni, hiszen egy-egy felôsoktatási intézményben fontos összefüggésekre mutathat rá a kevésbé erôs változók közötti kapcsolat is.

A kutatók azt is megvizsgálták, hogy az egyes tényezốcsoportok milyen arányban magyarázták az egyetemi tanulmányi átlagot. Jóllehet a személyiségtényezókkel való korreláció alacsony volt, a regresszióelemzés azt mutatta, hogy ezek a tényezôk is hozzájárulnak a tanulmányi eredményhez: a halogatás és a lelkiismeretesség a 7\%-át, a megismerési szükséglet és az érzelmi intelligencia az 5\%-át magyarázta a tanulmányi átlagnak. A három motivációs blokk 14\%-ot magyarázott a tanulmányi eredmények varianciájából, ahol az osztályzattal kapcsolatos cél és a tanulási énhatékonyság volt a legjobb elôrejelzô. Az önszabályozott tanulási stratégia 11\%-ot volt képes magyarázni, itt az erôfeszítés szabályozásának hatása volt a legerôsebb magyarázófaktor. A tanuláshoz való hozzáállás 9\%-ot magyarázott, és a stratégiai stílus volt a legerôsebb hatású tényezô a modellben. Ezek az eredmények azt igazolják, hogy az itt felsorolt pszichológiai konstruktumok független előrejelzôi, meghatározói lehetnek az egyetemi tanulmányi sikerességnek. A több tényezốcsoportot is magába foglaló hierarchikus regreszszióelemzés pedig azt mutatta, hogy kisebb, de nem elhanyagolható magyarázóereje van a pszichológiai jellemzôknek: a középiskolai tanulmányi eredmény és a kognitív képességek mérései 22\%-át magyarázták az egyetemi tanulmányi átlag varianciájának, és további 6\%-ot magyarázott az erófeszítés szabályozása, a tanulási énhatékonyság és az osztályzatra vonatkozó célkitûzés.

Az eredményekre támaszkodva Richardson és munkatársai (2012) azt hangsúlyozzák, hogy éppen azokat a nem kognitív pszichológiai konstruktumokat kell és lehet fejleszteni, módosítani, amelyek a legerôsebb kapcsolatban állnak a tanulmányi eredménnyel. Ilyen tényezók tehát a tanulással, osztályzattal kapcsolatos közeli és távoli célok, az - elsôsorban nehéz feladatok esetén fontossá váló - erôfeszítés szabályozása, a tanulással és teljesítménnyel kapcsolatos énhatékonyság-vélekedés. A képzés elején a leghatékonyabb ezeknek a pszichológiai tényezóknek a korrekciója és fejlesztése, mert ekkor a legerôsebb a köztük lévô együtt járás. A sokoldalú fejlesztés jelenti a legkedvezôbb és legtartósabb változást, és ezek közül a kognitív múködést célzó fejlesztések azok, amelyek meglehetôsen költségesek. A szerzôk azt is megállapítják, hogy az általános tanácsadásnál vagy stresszkezelố tréningeknél jobban növeli a tanulmányi eredményességet a teljesítményfókuszú intervenció.

\section{SZEMÉLYORIENTÁLT SZEMLÉLET A LEMORZSOLÓDÁS ÉS A SIKERES TANULMÁNYOK MAGYARÁZATAIBAN}

A változók között lineáris és mindenkire érvényes kapcsolatokat feltételezô, ún. változóorientált modellek mellett a lemorzsolódással kapcsolatban végzett kutatások között is megtalálhatók a személyorientált megközelítést alkalmazó tanulmányok. Ezek azt hangsúlyozzák, hogy egy-egy változóra, illetve a közöttük létezô kapcsolatra vonatkozó 
eredmények helyett jobb magyarázatot ad az egyetemi pályafutás különbségeire, ha feltárjuk azokat a hallgatói csoportokat, melyek eltéróen alkalmazkodnak az egyetemi körülményekhez bizonyos jellemzôk mintázatai alapján. Ezek a csoportok több, meghatározónak tartott változó különféle kombinációi mentén rajzolódnak ki, és nem egy változó magas vagy alacsony értéke adja a csoportokba sorolás lehetôségét. A felsôoktatási tanulmányi eredményességet sok különbözô változó befolyásolja, ezért indokolt annak vizsgálata, hogy a változók különbözô mintázata, dinamikája hogyan függ öszsze a tanulmányi teljesítménnyel (De Clercq, Galand és Frenay, 2017). Igy lehetôség nyílik annak megismerésére, hogy a különbözô típusba tartozó fiatalok közül melyik csoport múködik sikeresebben egy intézményen belül, illetve a változók különbözó mintázatai milyen alkalmazkodással járnak együtt.

A személyorientált vizsgálatok egyik csoportjában egy-egy pszichológiai funkción belüli mintázatokat kerestek azon felismerés alapján, hogy egy pszichés területen belül a domináns jellemzó mellett kisebb-nagyobb mértékben az adott funkció másfajta jellemzôje is megtalálható, és hatással van az egyén teljesítményére, viselkedésére. Ilyen hipotézis alapján Ratelle, Guay, Vallerand, Larose és Senécal (2007) arra keresték a választ, hogy milyen motivációs típusok találhatók a középiskolás és fôiskolás hallgatók körében, és melyik csoport ér el jobb tanulmányi teljesítményt. A szerzôk Shahar és munkatársainak eredményeire hivatkozva azt emelik ki, hogy az intrinzik és extrinzik motivációval szemben fontosabb szempont az, hogy autonóm vagy kontrollált motivációval jellemezhetô-e az egyén. Az autonóm motiváció esetén az egyén intrinzik vagy identifikált törekvések alapján maga kezdeményezi és irányítja a viselkedését, a kontrollált motivációnál viszont nem belsố indíttatású a cselekvés, hanem külsố vagy introjektált szabályozás irányítja az egyéni döntéseket és magatartást. Ratelle és munkacsoportja (2007) azt várta az egyetemi hallgatók vizsgálatakor, hogy a szabadabb és kevésbé kontrolláló felsôoktatási tanulmányok, szemben a középiskolai oktatással, jobban támogatják az autonóm motiváció megjelenését. Az eredmények három, egymástól jól elkülönülő motivációs profilt mutattak ki az elsôéves hallgatók körében. Az elsô, legnépesebb csoport az autonóm és a kontrollált motívumok területén is magas értéket ért el. A második csoportban mindkét motiváció alacsony értéket mutatott (itt több volt a férfi hallgató), míg a (nôi hallgatói többségû) harmadik csoport esetén egyedül az autonóm motívum szintje volt kiemelkedô. A második csoport tanulmányi eredménye volt a legalacsonyabb a három közül, és itt volt a legerôsebb a lemorzsolódási arány. Az elsố és a harmadik csoport hasonlóan jó tanulmányi eredményt ért el, de a tanulmányok folytatására a harmadik csoportban volt a legnagyobb esély. A szerzốk szerint az autonóm motiváció olyan kontextusra érzékeny hajtóerô, amely a kevésbé erôs külsố kényszer és kontroll esetén alakulhat ki, így a választott és preferált felsôoktatási képzés kedvezô környezetet biztosíthat a belsố motiváció kialakulásának és megerôsödésének.

Néhány vizsgálat a tanulmányi eredményesség helyett a mentális egészség mutatóit használja a hallgatói csoportok vizsgálatakor, hiszen a pszichológiai jóllét az egyik megbízható jelzése a felsôoktatási pályafutás sikerességének. Az érzelmi, szociális és önszabályozott tanulási énhatékonyság különbözó konfigurációját azonosították abban a követéses és két egymás utáni évben is elvégzett vizsgálatban, amelyben csaknem 1700 elsôéves hallgatót kérdeztek ki az énhatékonyság-vélekedésekrôl, valamint a 
depresszív tünetekrôl és az élettel való elégedettségrôl (Paciello, Ghezzi, Tramontano, Barbaranelli és Fida, 2016). Az egyéves különbséggel elvégzett vizsgálat nem talált eltérést a két kohorsz között egyetlen változóban sem. Az énhatékonyág három területének klaszteranalízise négy csoport létezését igazolta. A pszichés jóllét szempontjából a magas énhatékonyságú (mindhárom területen magas pontszámot elérô) csoport volt a leginkább elégedett és a legkevésbé depressziós, az alacsony énhatékonyságú csoport (a legalacsonyabb értékek a három énhatékonyságban) pedig ennek éppen az ellenkezőjét képviselte mindkét mérési időpontban. A tanulmányi és szociális területen magas értéket elérô, illetve csak az érzelmi hatékonyságban kiemelkedô hallgatói csoportok közepes szintjét mutatták a jóllétnek, de a tanulmányi-szociális csoportra nagyobb pszichológiai jóllét volt jellemzô, míg a depresszió értékében nem különböztek. A szerzók értelmezése szerint az eredmények azt igazolják, hogy a fiatalok majdnem felénél a különbözô területekhez tartozó énhatékonyság szorosan együtt jár, és az énhatékonyságról alkotott pozitív vagy negatív megfogalmazás erôs kapcsolatot mutat a pszichés alkalmazkodás sikerével vagy kockázatával. A hallgatók másik felénél viszont kompenzációs hatásként lehet értelmezni, hogy míg az egyik területen az énhatékonyság alacsonyabb, addig a másik területen magasabb énhatékonyság-vélekedés alakult ki. Ennél a két csoportnál az is látszik, hogy a tanulási-társas énhatékonyságú csoport alkalmazkodása, ha egy szempontból is, de sikeresebbnek mondható, mint az érzelmi énhatékonyságot észlelő csoporté.

A személyorientált vizsgálatok másik csoportja többféle pszichológiai funkció mintázatait tárja fel, és arra keresi a választ, hogy mi jellemzô az egyes csoportokba, klaszterekbe kerülő fiatalok egyetemi pályafutására, teljesítményére. Három, hagyományosan külön vizsgált oktatáspszichológiai fogalom összekapcsolása alapján például jól kirajzolódtak azok a hallgatói csoportok, akik sikeresen vagy sok kudarccal végezték a felsôoktatási tanulmányaikat (Heikkilä, Niemivirta, Nieminen és Lonka, 2011). A három elméletileg is különbözô terület a tanulási megközelítés (mély és felszínt érintô tanulási módszer), a tanulás önszabályozása, illetve a kognitív és attribúciós stratégiák (pl. feladatirreleváns cselekvés, társas támasz, reflektív gondolkodás) alkalmazása volt. A latens klaszterelemzésben a felhasznált változók három csoportot hoztak létre, a maladaptívnak tartott „nem akadémiai” és „gyámoltalan” csoportot, valamint a sikeresen alkalmazkodó „önirányított” csoportot. A csoportok eredményeinek értelmezésekor a szerzók a „nem akadémiai” csoport profilját látták a legkülönösebbnek. Ebben a csoportban volt a legalacsonyabb a jó tanulmányi teljesítményhez szükséges mély feldolgozás, kritikai értékelés és önszabályozás értéke, ugyanakkor a tanulmányi eredményük átlagos volt, a kimerüléspontszámuk magas értéket ért el, de a stresszpontszám alacsonyat. A szerzók úgy értelmezték ezeket az eredményeket, hogy ennek a csoportnak inkább instrumentális, a munka világa felé orientálódó motivációja van, ami a tanulmányok gyors, de nem biztos, hogy jó eredménnyel járó befejezését teszi lehetôvé. Az „önirányított” csoportra jellemzô volt a sikeres tanulmányi teljesítmény, a siker elvárása, a mélytanulás, a gyenge stressz és kimerülés észlelése, így ók azok, akik valószínúleg elkötelezettek a tanulmányok végzésével, amit jellemez az erôfeszítés és odaadás érzése. A „gyámoltalan” hallgatók alacsony önszabályozási és közepes szintú tanulási módszert mutattak, ók érték el a legalacsonyabb tanulmányi teljesítményt és a legmagasabb stressz- és kimerülésértékeket. Ennek az önkiszolgáló stratégiának a 
hátterében valószínúleg a tanulási környezet és a tanulási képességek csekély mértékú összeillése áll. A szerzók szerint a maladaptív kognitív és motivációs profilt mutató hallgatók (az elsôévesek kb. kétharmada) a képzés sajátosságait tükrözik inkább, és nem az egyéni vonásokat. Az egyetemi képzés elején jellemzó tömegoktatás ugyanis nem várja el a hallgatók személyes elkötelezôdését a tanulás iránt, és így ez az elkötelezettség nem is alakulhat ki sok fiatalnál (Heikkilä és mtsai, 2011).

Tanulási mintázatot emelt a vizsgálat fókuszába az a magyar kutatás, amely a beiratkozott hallgatók csoportjában kívánta azonosítani a lemorzsolódás szempontjából veszélyeztetett fiatalokat (D. Molnár és Gál, 2019). A tanulási mintázatot több pszichológiai funkció mentén vizsgálták, a tanulási stratégiák és motívumok mellett tanulási (pl. szorgalom, akadémiai önhatékonyság) és énattitúdök (pl. élettel való elégedettség, nyitottág a problémára) is szerepeltek a kérdôívben. A feltáró faktorelemzés öt olyan faktort igazolt, amelyet a szerzók tanulási mintázatnak neveztek el. Az öt tanulási mintázatot felhasználva klaszteranalízissel hat hallgatói csoportot lehetett azonosítani. Ebbôl három csoportnál (a vizsgált hallgatók felénél) olyan pozitív tanulási mintázat mutatkozott (pl. erôfeszítésen alapuló tanulás, fejlôdésre törekvés, együttmúködés és rugalmasság, teljesítményorientáció), amely alapján nem valószínúsíthetô a késôbbi lemorzsolódás. A tanulmányok felfüggesztésének veszélye a „rosszul tanulóknál” és a „lézengốknél” volt elôrejelezhetô. Az elôbbi csoportnál a pozitív tanulási jellemzôkbôl egy sem mutatkozott meg, csak a maladaptív tanulás, amely a halogatást, érzelmekre hagyatkozást, monitorozás hiányát és az élettel való elégedetlenséget tartalmazta. A „lézengôknél” a teljesítményorientáció hiánya volt a leginkább jellemzô, és emellett nem jelent meg a fejlôdésre, megértésre, erôfeszítésre való törekvés, sốt a maladaptív tanulás sem. A felvételi pontszám és a kompetenciamérés (olvasás, matematika) eredményei is azt mutatták, hogy az a csoport teljesített legjobban ezeken a területeken, akik pozitív tanulásmintázattal és a maladaptív tanulás hiányával jellemezték magukat, szemben a „rosszul tanulókkal” és a „lézengókkel”.

A középiskolai teljesítmény, a szocioökonómiai státusz és az énhatékonyság-vélekedés mellett a tanulmányok informált választása került a fókuszba abban a belgiumi vizsgálatban, amelyben hat hallgatói klaszter rajzolódott ki a több mint 2000 hallgató kérdőíves válaszai során (De Clercq és mtsai, 2017). Az „előnyök nélküli” csoportba azok kerültek, akik az átlaghoz viszonyítva mind a négy változóban alacsonyabb pontszámot kaptak. Az év végére ók érték el a leggyengébb egyetemi átlagot, kétharmaduk nem teljesítette az elsô év befejezéséhez szükséges tanulmányi eredmény szintjét. A „rosszul teljesítôk” csoportja az átlaghoz képest sokkal gyengébb középiskolai tanulmányi átlaggal rendelkezett, kedvezőbb társadalmi rétegból származott, és a tanulmányok választásában is tájékozottabb volt. A „meggondolatlan” profilt a gyenge középiskolai tanulmányt elérók és a tanulmányokkal kapcsolatosan kevéssé tájékozott fiatalok alkották, akikre a jobb társadalmi háttér és a határozottabb énhatékonyság-vélekedés volt még jellemzô. A negyedik csoportot, a „hátrányos helyzetûek”-et a legalacsonyabb szocioökonómiai státuszú hallgatók alkották, akik ugyanakkor magabiztosak voltak a siker eléréséhez szükséges képességeiket illetôen. Ennek a négy csoportnak a teljesítményátlaga a megkívánt tanulmányi (60\%-os) szint alatt volt, és az idesorolható hallgatók nagy része nem teljesítette az elsó év követelményeit. Az „aggodalmaskodó” csoporthoz tartozó fiatalok csak az énhatékonyság terén értek el átlag alatti értéket, 
minden más változóban magas pontszámot kaptak. Az „előnyös” profilt pedig az a csoport jelentette, akik mind a négy vizsgált mutatóban átlag feletti értékkel rendelkeztek. Az „aggodalmaskodó” és az „elônyös” csoport tagjai ugyanolyan módon sikeresen teljesítették az elsô évfolyam követelményeit. A szerzők azt hangsúlyozták, hogy valóban kirajzolódnak olyan hallgatói profilok, amelyek kapcsolatban állnak az egyetemi teljesítménnyel. Ezek a belépési profilok ugyanakkor csak 13\%-át magyarázták az év végi eredmények varianciájának, tehát a vizsgált belépési változók ilyen mintázatának prediktív értéke nem túl erôs. Mivel minden csoportban volt sikeres és sikertelen hallgató is, ez rámutat arra, hogy az év során jelentkezô teljesítmények hatását is figyelembe kell venni mint magyarázó faktort.

\section{MEGVITATÁS}

Tanulmányunkban kísérletet tettünk a felsôoktatási lemorzsolódás modelljeinek, újabb eredményeinek és megközelítésmódjainak összefoglaló és rendszerezó bemutatására négy szempont alapján, amelyet a szakirodalmi anyag áttekintésekor alakítottunk ki. Nemcsak a tudományos eredmények sokféleségével találkoztunk az anyaggyújtés során, hanem a lemorzsolódás jelenségének sokféle meghatározásával is, jóllehet ez a téma igen régóta jelen van a szociológiai és a pszichológiai kutatásokban (Pusztai és mtsai, 2019a; Szemerszki, 2018).

A magyar felsôfokú alapképzésbe beiratkozó hallgatók jelentôs része diploma nélkül hagyja el a felsôoktatást, a lemorzsolódás aránya tehát igen magas (Ceglédi, 2019; Pusztai és mtsai, 2019b), és ezt a felsôoktatás irányítói, az intézmények vezetôi, oktatói és hallgatói is jelentôs problémának tekintik, bár vannak olyan szerzók, akik nem látnak patológiás jelenséget a tanulmányok korai befejezésében (Kun, 2015, id. Pusztai és mtsai, 2019b). Tulajdonképpen ma sincs végleges, sokak által elfogadott meghatározása a lemorzsolódásnak (Miskolczi és mtsai, 2018; Czakó és mtsai, 2019). Az angol nyelvterületen például több, eltérôen használt és értelmezett kifejezést használnak a felsôoktatási képzés megszakításának vagy folytatásának leírására attól függôen, hogy az egyén vagy az intézmény kompetenciáit hangsúlyozzák, például dropout, attrition, persistence, retention (Szöllósi, 2019). Bár a szóhasználat, a vizsgálati módszerek, a felsôoktatási képzés szerkezetének heterogenitása miatt eltérô definícióját láthatjuk a lemorzsolódásnak, az egyén tervei és kudarcai vagy sikerei szempontjából lényegesnek tûnik annak a megkülönböztetése, hogy a fiatal szándékosan vagy kényszerbôl hagyja el végleg diploma nélkül a felsôoktatást (Miskolczi és mtsai, 2018). További fontos szempont, hogy a kilépés után valamilyen módon, akár késóbb, más intézményben és képzésben van-e lehetôsége a diplomaszerzésre, amelyet biztosíthat az életszakaszok és a tanulási utak sokfélesége (Ceglédi, 2019).

A lemorzsolódásnak sokféle valószínúsítő tényezőjét ismerhetjük meg a kiterjedt szakirodalomból, és ezeknek a tényezôknek vagy a tényezók egy kiemelt csoportjának sokféle csoportosítása létezik (Kerülô, 2018; Miskolczi és mtsai, 2018; Pusztai, 2019; Quinn, 2013). Tanulmányunkban egy olyan faktorrendszert mutattunk be és illusztráltunk különbözó tanulmányok említésével, amely tartalmazza a társadalmi és politikai tényezôktôl kezdve a családi és intézményi hatásokat, és az egyénre jellemzô fakto- 
rokat is (Quinn, 2013). A különbözô csoportosítás mentén kirajzolódó fôbb faktorok áttekintésének szerepét elsôsorban abban látjuk, hogy ennek segítségével jobban elkülöníthetôk és lokalizálhatók a lemorzsolódás tényezôi, ami ilyen módon segíthet az intervenció szintjeinek és hatásának megtervezésében is. A különbözó befolyásoló tényezôk számbavétele ugyanakkor nem teszi lehetôvé, hogy az egyes faktorok súlyát, egymásra hatását vagy rendszerszintú kapcsolatait megismerjük.

A lemorzsolódás kutatásában már régóta jelen vannak a különbözô modellek, amelyek összefoglalják a megismert tényezôket és ezek összefüggését, illetve kiemelik a legfontosabbnak tartott meghatározókat. A modellek nemcsak integrálják az ismereteket, hanem igazoló és cáfoló vizsgálatok végzésére is ösztönzik a kutatókat. Az áttekintett modellekból Tinto (1975) és Cabrera és munkatársai (1993) lemorzsolódási útvonala áll a legközelebb egymáshoz, jóllehet Cabrera és munkatársai Tinto és Bean modelljének ötvözésével alakították ki a saját modelljüket. A hasonlóság elsôsorban abban ragadható meg, hogy mindkét modell hangsúlyozza a hallgató és az intézmény interakcióját, továbbá egy hosszabb-rövidebb folyamatnak tekintik a lemorzsolódást, illetve a tanulmányok folytatását. A modellek szinte ugyanazokkal a meghatározó faktorokkal (és fogalmakkal) jellemezhetôk: cél- és intézményi elkötelezettséggel és az egyetemi/tanulmányi és társas integrációval. De markáns különbséget is láthatunk közöttük. Tinto úgy gondolja, hogy a belépéskor tanúsított elkötelezettségek befolyásolják az egyetemi és társas rendszerrel való interakciót és így az integrációt, és ez hat az elkötelezettség késôbbi alakulására, ami befolyásolja a lemorzsolódási döntést. Cabrera és munkatársainak empirikusan is alátámasztott modellje a bennmaradást kívánja értelmezni, és itt a háttértényezókhöz kapcsolódó integráció (tanulmányi és társas) gyakorol hatást a cél- és intézményi elkötelezettségre, tehát nem jelentôs, vagy nincs is korábbi (belépéskor jellemzô) elkötelezettség. Mindkét modell említi a családi háttértényezôt, de a Tinto-féle modell kevésbé hangsúlyozza az anyagi körülményeket, ugyanakkor határozottabban kiemeli a korábbi oktatási tapasztalatokat, illetve az egyéni jellemzôket. Tinto hosszabb folyamatát írja le a lemorzsolódási tervnek, amelyben a családi értékekrôl való leválás után jöhet létre az átmenet, és késôbb az új elkötelezettséget formáló inkorporáció. Cabrera modelljének sajátja viszont a maradási szándék figyelembevételén túl a perzisztencia tényének hangsúlyozása.

A Bean-féle Hallgató Kilépésének Modellje is az egyén és az intézmény interakcióját említi a lemorzsolódással kapcsolatban, de a faktorok meghatározásakor és ezek múködésének leírásakor szociálpszichológiai összefüggést hangsúlyoz, nevezetesen az attitûd-szándék-viselkedés oksági kapcsolatot (Bean, 1981a, 1981b). A háttérváltozók, vagyis az egyetemre történô beiratkozás elôtti attitûdök és tervek itt is szerepet kapnak, és ezek kapcsolódnak szervezeti (intézményi múködésben való részvétel), személyi (pl. önbizalom, céllal kapcsolatos elkötelezettség) és környezeti (egyetemi szférán kívül esô) változókkal. Az egyén és intézmény interakciójából alakul ki az a hallgatói attitûd, amely az elégedettségre, a diploma, illetve a képzés fontosságára, értékességére vonatkozik. A háttér, a környezet három eleme és a tapasztalatok nyomán kialakult attitûd okozzák a lemorzsolódási szándékot, ami végül meghatározza a kilépést. Az attitûd-viselkedés kapcsolatának hangsúlyozása ellenére ez a modell is kiemeli azokat a tényezôket, amelyeket a Tinto- és a Cabrera-féle modellben láthattunk. A szervezeti és az attitúdváltozóban tulajdonképpen hasonló elemeket említ Bean (céllal kapcso- 
latos elkötelezettség, szak választásával kapcsolatos bizonyosság, elégedettség a hallgatói léttel, hûség az intézménnyel kapcsolatban), mint a tintói modellben szereplố (cél- és intézményi) elkötelezettség. Ami mégis nagy különbségnek számít, az egyrészt a változók sokszor újszerú meghatározása (például az önértékelés, a képzés gyakorlati hasznosságának beemelése) és a kortársi kapcsolatok rendszerének gyenge súlya, így a modell inkább egy társas vákuumban élô, az egyén és a konkrét intézmény kapcsolatának megítélésén alapuló döntéshozatalt vázol fel.

Bennett útvonalmodellje (2003, id. Lukács és Sebô, 2015), bár az elkötelezettséget helyezi a középpontba, sok szempontból mégis eltér az elôzôktôl. Egyrészt egy sajátos helyzetú, anyagi nehézségekkel küzdô egyetemista csoport empirikus adataiból építkezik a kilépni-maradni döntés során, másrészt igen sokféle pszichológiai konstruktumot használ fel a bejósló tényezôk között. A pszichológiai jellemzók (pl. önbecsülés, motiváció) mellett a tanulmányokkal kapcsolatos változók is hangsúlyosak, így került be a modellbe a tanulmányi teljesítmény, tanulási stratégia és szokások változója is. A modell egyik legfontosabb eleme, amely a menni-maradni dilemmára hat, az elkötelezettség az egyetemi oktatással és szolgáltatásokkal kapcsolatban, amelyre hatnak a motiváción keresztül a tanulással kapcsolatos tapasztalatok. Az elkötelezettséget az elégedettség és a személyes befektetés is befolyásolja, de az anyagi és személyes problémák közvetlenül a döntéshez kapcsolódnak, tehát önálló szerepük van a kilépési elképzelés meghozatalakor. Ebben a modellben is megtalálhatók az oktatói és a társas kapcsolatok tényezői, de ezek a motiváción keresztül fejtik ki hatásukat. A modellre jellemzó, hogy a menni vagy maradni döntést helyezi a középpontba, amelyet meghatároz a sok tényezô által formált elkötelezettség, az objektív (anyagi és személyes) problémák egy csoportja, valamint a tanulmányi eredmény, amely egyéb folyamatokon keresztül is hatást gyakorol az elkötelezettségre. A modell tehát az objektív faktorok mellett a meghatározó tényezôk személyesebb, egyéni tapasztalatokban és képességekben kifejezôdố hatásrendszerét rajzolja meg, amelyben a tanulmányi teljesítmény több útvonalon keresztül is befolyásolja a tanulmányok folytatásával kapcsolatos terveket. Az empirikus adatok azt mutatták, hogy bár a minta sajátosságai miatt döntô tényezô a lemorzsolódásban az anyagi nehézség, de ennek a hatását módosíthatja a tanulmányi teljesítmény, az elkötelezettség és az önbecsülés (Lukács és Sebô, 2015; Miskolczi és mtsai, 2018), vagyis a modell a tényezốk súlyára, kapcsolatára is érzékeny.

Az elôzô modellek sok elemét tartalmazzák az egyén és a többé-kevésbé általánosítható intézmény kapcsolatának, amelyben a hallgatók belépéskor adott jellemzói, sajátosságai találkoznak az intézményi múködéssel és elvárásokkal, és e megfelelés minốsége alakítja ki a hallgatói döntést és viselkedést a tanulmányok folytatásával kapcsolatban. Ezeknek a modelleknek a fókuszából nagyrészt hiányzik az, hogy a lemorzsolódás értelmezésének, a társas közegben történố jelentésadásnak is szerepe van a hallgatók és az intézmények viselkedésének formálódásában, valamint a magukról és a másikról alkotott percepciónak az alakulásában. A modellek közül Bean modellje az, ami hangsúlyozza, hogy a hallgatók észlelése és értelmezése fontos az attitûdök kialakításában, illetve néhány tanulmány is említi a hallgatói észlelések vizsgálatának fontosságát (Pusztai, 2018a, 2019). A szociális konstrukcionizmus szemléletét alkalmazó értelmezések vizsgálatánál olyan területeket jelölt ki Szöllôsi (2019), amelyek korábban ritkán kerültek a vizsgálatok és a modellek középpontjába (pl. a felsôoktatási tanulmányok és a tanulás értéke, a közösségekhez való tartozás jelentése). Ez az új 
szemléletmód lehetôvé teszi, hogy a részben már ismert jelenséget egy újabb szempontból is megvizsgálják, és megértsék a jövôbeli kutatások.

Mivel a Quinn-féle kategóriákban csak részlegesen jelent meg a pszichológiai funkciók lemorzsolódással kapcsolatos szerepe (pl. mentális múködés, elkötelezettségek, tanulással kapcsolatos tényezók), így külön fejezetet szenteltünk ezek összegyújtésének, ami egyfajta rálátást nyújthat a megvizsgált pszichés funkciókra. Richardson és munkatársai (2012) metaanalízissel készült tanulmánya igen nagyszámú pszichológiai konstruktumot tudott azonosítani, amelyek nem tekinthetôk intellektuális képességnek, és amelyek különbözô módon korreláltak az egyetemi tanulmányi teljesítménynyel. Az összefoglaló cikk ilyen módon egyrészt kibôvítette a lemorzsolódás témakörét a tanulmányi eredményességgel, ami ezáltal beemelte a sikeres vagy sikertelen egyetemi pályafutás szempontját a vizsgálandó tényezôk közé, így a lemorzsolódás elôtt gyakran megjelenó teljesítményprobléma (pl. kevés kredit teljesítése, elmulasztott vizsgaalkalmak) felé is nagyobb figyelemmel fordulhatnak a kutatások. Másrészt a szerzôk arra is választ adtak, hogy a sokféle pszichés tényezó közül melyik és milyen mértékben áll kapcsolatban a tanulmányi teljesítménnyel, illetve milyen mértékben magyarázta azt. Nem meglepó, hogy a motivációs és az önszabályozott tanulási stratégiák néhány eleme korrelált nagyobb mértékben a tanulmányi eredménnyel, és ezek jobban magyarázták a tanulmányi elômenetelt. Ugyanakkor érdemes azt is figyelembe venni, hogy a gyengén korreláló tényezôk is befolyásolhatják a hallgatók egyetemi pályafutását, hiszen a pszichológiai konstruktumok egymást erôsítô, támogató vagy éppen gyengítô kapcsolata az egyénen belül hatással lehet a tanulmányi eredményességre. A metaanalízis eredményeit mégis óvatosan lehet csak általánosítani, hiszen az említett pszichés faktoroknak eltérô súlya és hatása lehet a különbözô kultúrákban és intézményekben. Ezen túl a pszichológiai konstruktumokat inkább statikus változókként kezeli a megközelítés, és nem veszi figyelembe a felsôoktatási környezettel folytatott interakció befolyásoló hatását a hallgatók sikerei vagy kudarca során.

Újfajta szemléletet és gyakorlatot hoztak a lemorzsolódás vizsgálatának területén azok a kutatások, amelyek többféle pszichológiai konstruktum mintázatát hozták öszszefüggésbe az egyetemi tanulmányi teljesítménnyel. A személyorientált vizsgálatok egyrészt hangsúlyozzák a pszichés tényezók szerepét a felsôoktatási tanulmányi pályafutásban, másrészt meghaladják a néhány tényezô magas vagy alacsony értékével történô magyarázatokat azáltal, hogy típusokat, mintázatokat képeznek a különbözô változókból. A vizsgálati eredmények azt mutatják, hogy sokféle pszichológiai jellemzô mintázata alkalmas arra, hogy a tanulmányi teljesítményt vagy a pszichológiai jóllétet elôre jelezze, ez utóbbi változó ugyanis szintén jó jellemzôje a sikeres egyetemi alkalmazkodásnak (Ratelle és mtsai, 2007; Paciello és mtsai, 2016; Heikkila és mtsai, 2011; D. Molnár és Gál, 2019). A hallgatói típusok kialakításával sokkal árnyaltabb kép kapható, különösen akkor, ha nemcsak a lemorzsolódásra fókuszálunk, hanem a tanulmányi pályafutást, eredményességet, elômenetelt is figyelembe vesszük. Ugyanakkor a pszichológiai jellemzók kiválasztásának elméleti megalapozottsága vagy elôzó empirikus eredményekre való támaszkodása jelentôsen befolyásolja, hogy a kirajzolódó mintázatok milyen jól tudják magyarázni a tanulmányi teljesítményt, illetve a lemorzsolódást. A hallgatók különbözô pszichés tényezôk szerinti mintázata statikus képet is mutathat, de a változás lehetôségét is tartalmazhatja attól függóen, hogy milyen konstruktumot választ be a vizsgált tényezók közé egy-egy kutatási projekt. 


\section{TOVÁBBLÉPÉSI LEHETŐSÉGEK}

Az áttekintett szakirodalmi tanulmányok alapján kirajzolódni látszik néhány olyan szempont, amelyek a további kutatásokban felhasználhatók, és amelyek alkalmazásával a beavatkozási lehetôségek is kialakíthatók.

A lemorzsolódás fogalmának sokfélesége valószínúleg továbbra is fennmarad, ami, túl a jelenség heterogenitásán, a definíciók eltérése mellett a mérési különbségekből és az adatok hozzáférési lehetốségeibôl is adódik. Ugyanakkor - különösen az intervenciós lehetôségek oldaláról - érdemes lenne a lemorzsolódás jelenségét a tanulmányi pályafutás, az egyetemi karrier, illetve a fiatal (kezdôdô) felnôttkori életutak nagyobb rendszerébe beleilleszteni, amelynek során jobban megismerhetôk, megérthetốk és esetleg kanalizálhatók lehetnének a fiatalok pályamódosításai, változtatási szándékai. A fiatal korosztály egyetemi életének, pályafutásának és pályakorrekciós elképzeléseinek megismerése a folyamatok feltárása és megértése miatt is fontos lenne, ugyanakkor ennek nyomán adekvátabb prevenciós és intervenciós lehetôségek kialakítására nyílna mód. A hallgatók percepciójának, szociális reprezentációjának vizsgálata több területtel kapcsolatban is újabb eredményeket hozhat a kutatások fókuszába és a beavatkozási folyamatok kialakításába. Ilyen területnek tekinthetôk például a saját teljesítményről, a képességeik fejlődésérôl, a külsô támogató forrásokról, a szakma és tanulmányok összeillésérôl szóló nézetek. A prevenciós és intervenciós programokkal kapcsolatban csak egy szempontot emelnénk ki, és az a korai beavatkozás szerepe. A különbözô vizsgálatok azt jelezték, hogy az elsô két félévben a legnagyobb a lemorzsolódás, tehát a korrekciós, támogató módszerek propagálását és elérhetôségét preventív jelleggel már az elsố két félévben érdemes megszervezni.

A hallgatói értelmezések nemcsak a saját helyzetükkel és az intézmény múködésével kapcsolatban lehetnek informatívak, hanem a kortársak szerepét illetôen is. Emellett a tényleges kortársi kapcsolatoknak, illetve a fiatal felnôttek szubkultúrájának megismerése is segítheti a hallgatók perzisztenciájának támogatását.

A szakirodalmi áttekintésbôl látható, hogy az intézményre vonatkozó jellemzốk leírása igen hiányos, bár a legtöbb tanulmány és több megközelítésmód is hangsúlyozza, hogy az intézményi sajátosságok és az egyéni attribútumok interakciója határozza meg a lemorzsolódást és a tanulmányok melletti kitartást. Jóllehet az intézmény-hallgató kapcsolatában az intézményi oldal tekinthetố nehezebben módosíthatónak, a változásokra ez az interakciós partner is válaszol a különbözố társadalmi kihívások és oktatáspolitikai intézkedések kapcsán. Ezeknek a változásoknak a megismerése is segítheti a hallgató-intézmény összeillésének erôsítését, különösen akkor, ha ebben a feltárási folyamatban helyet kap az intézmény különbözô szintjeinek szociális reprezentációja önmagáról és a hallgatókról. Ezek az ismeretek végül is a helyi megelôzoó és korrigáló programok kialakítását is segíthetik.

A lemorzsolódás megértésében és csökkentésében nemcsak az új kérdések és az új válaszok megtalálása segíthet, hanem a különbözô szakterületek együttmúködése. Szociológusok, oktatási szakemberek és pszichológusok párbeszéde és közös kutatási projektjei az eltérô szemléletmódok mellett is hozzájárulhatnak a sikeresebb és rugalmasabban mû́ködô hallgató-intézmény interakció kialakításához. 


\section{KÖSZÖNETNYILVÁNÍTÁS}

A szerzók kutatási támogatásban részesültek az EFOP-3.4.3-16-2016-00014 „A Szegedi Tudományegyetem oktatási és szolgáltatási teljesítményének innovatív fejlesztése a munkaerô-piaci és a nemzetközi verseny kihívásaira való felkészülés jegyében" projekt keretében, amit ezúton is köszönünk.

\section{IRODALOM}

Ajzen, I., \& Fishbein, M. (1973). Attitudinal and normative variables as predictors of specific behavior. Journal of Personality and Social Psychology, 27(1), 41-57.

Andrews, B., \& Wilding, J. M. (2004). The relation of depression and anxiety to life-stress and achievement in students. British Journal of Psychology, 95, 509-521.

Araque, F., Roldán, C., \& Salguero, A. (2009). Factors influencing university drop out rates. Computers and Education, 53(3), 563-574.

Arendt, J. N. (2013). The effect of public financial aid on dropout and competion of university education: evidence from a student grant reform. Empirical Economics, 44(3), 1545-1562.

Bean, J. P. (1981a). Student attrition, intentions, and confidence: Interaction effect in a path model. Part I., The 23 variable model. Paper presented at the Annual Meeting of the Educational Research Association, Los Angeles, CA, Apil, 13-17. 1981. 48.

Bean, J. P. (1981b). The synthesis of theoretical model of student attrition. Paper presented at the Annual Meeting of the Educational Research Association, Los Angeles, CA, Apil, 13-17. 1981. 34.

Bers, T. H., \& Smith, K. E. (1991). Persistence of community college students: The influence of student intent and academic and social integration. Research in Higher Education, 32(5), 539-556.

Cabrera, A. F., Nora, A., \& Castaneda, M. B. (1993). College persistence: structural equations modeling test of an integrated model of student retention. Journal of Higher Education, 64(2), 123-139.

Ceglédi, T. (2019). Potyázók, anómiások, rituális perzisztensek és célorientált perzisztensek. A hallgatói lemorzsolódás szokatlan veszélyei. Acta Medicinae et Siciologica, 10(28), 45-62.

Czakó, A., Németh, L., \& Felvinczi, K. (2019). A felsôfokú képzés befejezésére irányuló szándék előrejelzôii. Educatio, 28(4), 718-736. DOI: 10.1556/2063.28.2019.4.5

Csók, C., Dusa, Á. R., Hrabéczy, A., Novák, I., Karászi, Zs., Ludescher, G., et al. (2018) . A hallgatói lemorzsolódás és háttértényezôi egy kvalitatív kutatás tükrében. In Pusztai, G., \& Szigeti, F. (Eds), Lemorzsolódás és perzisztencia a felsôoktatásban (pp. 38-62). Debrecen: Debreceni Egyetemi Kiadó.

De Clercq, M., Galand, B., \& Frenay, M. (2017). Transition from high school to university: a person-centered approach to academic achievement. European Journal of Psychology of Education, 32(1), 39-59. DOI: 10.1007/s10212-016-0298-5

Dinyáné Szabó, M., Pusztai, G., \& Szemerszki, M. (2019). Lemorzsolódási kockázat az orvostanhallgatók körében. Orvosi Hetilap, 160(21), 829-834.

D. Molnár, É., \& Gál, Z. (2019). Egyetemi tanulmányaikat megkezdő hallgatók tanulási mintázata és tanulói profilja. Iskolakultúra, 29(1), 29-41. DOI: 10.17543/ISKKULT.2019.1.29

Doll, J. J., Eslami, Z., \& Walters, L. (2013). Understanding why students drop out of high school, according their own reports: are they pushed or pulled, or do they fall out? A comparative analysis of seven natiomally representative studies. Sage Open, 1-15. DOI: 10.1177/2158244013503834

Elkins, S. S., Braxton, J. M., \& James, G. W. (2000). Tinto's separation stage and its infuence on first-semester college students persistence. Research in Higher Education, 41(2), 251-268. 
Ganyaupfu, E. M. (2013). Factors influencing academic achievement in quantitative courses among business students of private higher education institutions. Journal Education and Practice, 4(15), 57-64.

Heikkilä, A., Niemivirta, M., Nieminen, J., \& Lonka, K. (2011). Interrelations among university students' approaches to learning, regulation of learning and cognitive and attributional strategies: a person oriented approach. Higher Education, 61, 513-529. DOI: 10.1007/ s10734-010-9346-2

Herzog, S. (2005). Measuring determinants of student return vs. dropout/stopout vs. transfer: a first-to-second year analysis of new freshmen. Research in Higher Education, 46(8), 883-928.

Hódi, Á., \& Tóth, E. (2019). Elsôéves egyetemi hallgatók szövegértés fejlettsége és olvasási attitûdjei. Iskolakultúra, 29(1), 55-67. DOI: 10.17543/ISKKULT.2019.1.55

Kerülô, J. (2018). „Menni vagy maradni” - Lemorzsolódás a felsôoktatási intézményekben, okok és megoldási javaslatok. In Pusztai, G., \& Szigeti, F. (Eds), Lemorzsolódás és perzisztencia a felsôoktatásban (pp. 170-188). Debrecen: Debreceni Egyetemi Kiadó.

Ketonen, E. E., Haarala-Muhonen, A., Hirsto, L., Hänninen, J. J., Wähälä, K., \& Lonka, K. (2016) . Am I in the right place? Academic engagement and study success during the first years at university. Learning and Individual Differences, 51, 141-148. http:/ /dx.doi.org/10.1016/j.lindif.2016.08.017

Kovács, K. E. (2018). A motiváció szerepe a felsôoktatási lemorzsolódásban és perzisztenciában. Iskolakultúra, 28(10-11), 55-63. DOI: 10.17543/ISKKULT.2018.10-11.55

Kovács, K., Ceglédi, T., Csók, C., Demeter-Karászi Zs, Dusa, Á. R., Fényes, H., Hrabéczy, A., Kocsis, Zs., Kovács, K. E., Markos, V., Máté-Szabó, B., Németh, D. K., Pallay, K., Pusztai, G., Szigeti, F., Tóth, D. A. \& Váradi, J. (2019). Lemorzsolódott hallgatók 2018. Debrecen: Center for Higher Education Research \& Development - Hungary.

Lehmann, W. (2007). "I just didn't feel like I fit in": The role of habitus in university drop-out decisions. Canadian Journal of Higher Education, 37(2), 89-110.

Lendvai, E., Panyor, Á., \& Hampel, Gy. (2019). A Mérnöki Kar agrár és múszaki képzésein történô lemorzsolódás okainak feltárása tárgyában készült kérdôíves felmérés eredményei. Jelenkori Társadalmi és Gazdasági Folyamatok, 14(1), 205-210.

Lukács, F., \& Sebő, T. (2015). Az egyetemi lemorzsolódás kérdôíves vizsgálata. Iskolakultúra, 25(10), 78-86. DOI: 10.17543/ISKKULT.2015.10.78

Miskolczi, P., Bársony, F., \& Király, G. (2018). Hallgatói lemorzsolódás a felsôoktatásban: elméleti, magyarázati utak és kutatási eredmények összefoglalása. Iskolakultúra, 28(3-4), 87-105.

Molnár, Gy., \& Csapó, B. (2019). A felsôoktatási tanulmányi alkalmasság értékelésére kidolgozott rendszer a Szegedi Tudományegyetemen: elméleti keretek és mérési eredmények. Educatio, 28(4), 705-717. DOI: 10.1556/2063.28.2019.4.4

Murtaugh, P. A., Burns, L. D., \& Schuster, J. (1999). Predicting the retention of university students. Research in Higher Education, 40(3), 355-371.

Paciello, M., Ghezzi, V., Tramontano, C., Barbaranelli, C., \& Fida, R. (2016). Self-efficacy configurations and wellbeing in the academic context: a person centered approach. Pesonality and Individual Differences, 99, 16-21. doi.org/10.1016/j.paid.2016.04

Pusztai, G. (2018a). Ha elvész a bizalom. Educatio, 27(4), 623-639.

Pusztai, G. (2018b). Egy hatékony tényezô a lemorzsolódás mérséklésére. In Pusztai, G., \& Szigeti, F. (Eds), Lemorzsolódás és perzisztencia a felsôoktatásban (pp. 109-127). Debrecen: Debreceni Egyetemi Kiadó.

Pusztai, G. (2019). A lemorzsolódás oktatáspolitikai és döntéselméleti okai. In Kovács, K. (Ed.), Lemorzsolódott hallgatók 2018. (pp. 3-4). Debrecen.

Pusztai, G., Fónai, M., \& Bocsi, V. (2019a). A társadalmi státusz transzmissziója és a felsôoktatási lemorzsolódás. Acta Medicinae et Sociologica, 10(28), 5-23.

Pusztai, G., Kovács, K., \& Hegedûs, R. (2019b). Lemorzsolódók tegnap, ma és holnap. Educatio, 28(4), 737-754. DOI: 10.1556/2063.28.2019.4.6

Quinn, J. (2013). Drop-out and completion in higher education in Europe among students from under-represented group. Letöltve: 2017. 02. 06-án: http://www.nesetweb.eu 
Ratelle, C. F., Guay, F., Vallerand, R. J., Larose, S., \& Senécal, C. (2007). Autonomous, controlled and amotivated types of academic motivation: a person-oriented analysis. Journal of Educational Psychology, 99(4), 734-746.

Richardson, M., Abraham, C., \& Bond, R. (2012). Psychological Correlates of University Students' Academic Performance: A Systematic Review and Meta-Analysis. Psychological Bulletin, 138(2), 353-387.

Snyder, C. R., Shorey, H. S., Cheavens, J., Mann Pulvers, K., Adams, V. H., \& Wiklun, C. (2002). Hope and academic success in college. Journal of Educational Psychology, 94(4), 820-826.

Somlai, P. (2011). Nemzedéki konfliktusok és kötelékek. In Bauer, B., \& Szabó, A. (Eds), Arctalan (?) nemzedék. Ifjúság 2000-2010 (pp. 25-36). Budapest, Nemzeti Család- és Szociálpolitikai Intézet.

Szemerszki, M. (2018). Lemorzsolódási adatok és módszertani megfontolások. In Pusztai, G., \& Szigeti, F. (Eds), Lemorzsolódás és perzisztencia a felsôoktatásban (pp. 15-27). Debrecen: Debreceni Egyetemi Kiadó.

Szöllôsi, G. (2019). Az egyetemi hallgatók megtartását segítô eszközök a nemzetközi gyakorlatban: Elméletek és módszerek. Szociális Szemle, 12(1-2), 4-26. DOI: doi.org/10.15170/SocRev.2019.12.01-02.01

Tamin, S. K. (2013). Relevance of mental health issues in university student dropouts. Occupational Medicine, 63, 410-414.

Terenzini, P. T., \& Pascarella, E. T. (1980). Toward a validation of Tinto's model of college student attrition: a review of recent studies. Research in Higher Education, 12(3), 271-282.

Tinto, V. (1975). Dropout from Higher Education: A Theoretical Synthesis of Recent Research. Review of Educational Research, 45(1), 89-125.

Varga, J. (2010). Mennyit ér a diploma a kétezres években Magyarországon? Educatio, 3, 370-383.

\section{FACTORS AND EXPLANATIONS OF SUCCESSFUL AND UNSUCCESSFUL ACADEMIC PERFORMANCE IN HIGHER EDUCATION}

\section{DR. KŐRÖSSY, JUDIT - JAGODICS, BALÁZS - DR. MARTOS, TAMÁS - DR. SZABÓ, ÉVA}

Goals: The most significant challenge of higher education is dropout from college or leaving universities without degree in the last decades. In order to understand dropout phenomenon different theoretical and methodological approaches have been applied. The aim of our study is to overview the approaches, the focuses and the results of different studies concerning the student attrition. The description of different approaches can help to integrate existing information, to plan research proposals and to design intervention programs focusing on dropuot.

Methods: The studies about dropout in English and Hungarian languages have been selected from online database using relevant keywords. Papers were grouped according to their methods (variable- or person-oriented), topics and issues (causes of dropout, models, weight of variables, adjustment patters of students).

Results: Four groups have been formed based on the approaches of articles during the review. Three of them use variable-oriented analysis, and the fourth group consists of studies applying person-oriented approach. The four topic groups are analysed in detail: 1. Grouping of causal and influential factors, 2. Explanatory models of dropout, 3. Identifying psychological variables and its weight, 4. Academic adjustment of student groups formed by patterns of different variables.

Conclusions: The discussion highlights the advantages and weaknesses of different approaches concerning the dropout phenomenon. The last chapter of the paper emphasizes those new aspects which can be applied in further research on dropout and intervention programs.

Keywords: success in higher education, models of dropout, variable-oriented research, person-oriented approach 
A cikk a Creative Commons Attribution 4.0 International License https://creativecommons. org/licenses/by/4.0/) feltételei szerint publikált Open Access közlemény, melynek szellemében a cikk bármilyen médiumban szabadon felhasználható, megosztható és újraközölhetô, feltéve, hogy az eredeti szerzó és a közlés helye, illetve a CC License linkje és az esetlegesen végrehajtott módosítások feltüntetésre kerülnek. (SID_1) 